\title{
Enhancing bio-oil quality and energy recovery by atmospheric hydrodeoxygenation of wheat straw pyrolysis vapors using $\mathrm{Pt}$ and Mo-based catalysts
}

Eschenbacher, Andreas; Saraeian, Alireza; Shanks, Brent H.; Jensen, Peter Arendt; Li, Chengxin; Duus, Jens Øllgaard; Hansen, Asger Baltzer; Mentzel, Uffe Vie; Henriksen, Ulirik Birk; Ahrenfeldt, Jesper Total number of authors:

11

Published in:

Sustainable Energy \& Fuels

Link to article, DOI:

10.1039/C9SE01254K

Publication date:

2020

Document Version

Peer reviewed version

Link back to DTU Orbit

Citation (APA):

Eschenbacher, A., Saraeian, A., Shanks, B. H., Jensen, P. A., Li, C., Duus, J. Ø., Hansen, A. B., Mentzel, U. V., Henriksen, U. B., Ahrenfeldt, J., \& Jensen, A. D. (2020). Enhancing bio-oil quality and energy recovery by atmospheric hydrodeoxygenation of wheat straw pyrolysis vapors using Pt and Mo-based catalysts. Sustainable Energy \& Fuels, 2020(4), 1991-2008 . https://doi.org/10.1039/C9SE01254K

\section{General rights}

Copyright and moral rights for the publications made accessible in the public portal are retained by the authors and/or other copyright owners and it is a condition of accessing publications that users recognise and abide by the legal requirements associated with these rights.

- Users may download and print one copy of any publication from the public portal for the purpose of private study or research.

- You may not further distribute the material or use it for any profit-making activity or commercial gain

- You may freely distribute the URL identifying the publication in the public portal 


\section{Enhancing bio-oil quality and energy recovery by}

2 atmospheric hydrodeoxygenation of wheat straw

3 pyrolysis vapors using Pt and Mo-based catalysts

4 Andreas Eschenbacher ${ }^{\mathrm{a},}$, Alireza Saraeian ${ }^{b}$, Brent H. Shanks $^{b}$, Peter Arendt Jensen ${ }^{a}$, Chengxin

5 Li $^{c}$, Jens Øllgaard Duus ${ }^{c}$, Asger Baltzer Hansen ${ }^{d}$, Uffe Vie Mentzel ${ }^{d}$, Ulrik Birk Henriksen ${ }^{a}$,

6 Jesper Ahrenfeldt ${ }^{a}$, Anker Degn Jensen ${ }^{a, *}$

$7 \quad{ }^{a}$ Department of Chemical and Biochemical Engineering, Technical University of Denmark, 2800

8 Kgs. Lyngby, Denmark

$9{ }^{b}$ Department of Chemical and Biological Engineering, Iowa State University, Ames, IA 50011,

$10 \quad$ United States

$11{ }^{\mathrm{c}}$ Department of Chemistry, Technical University of Denmark, 2800 Kgs. Lyngby, Denmark

$12{ }^{\mathrm{d}}$ Haldor Topsøe A/S, 2800 Kgs. Lyngby, Denmark

13 KEYWORDS. Wheat Straw; Bio-oil; Fast Pyrolysis; Hydrodeoxygenation; $\mathrm{TiO}_{2}$-supported

14 catalysts; catalysis

15 


\section{ABSTRACT}

17 Atmospheric hydrodeoxygenation (HDO) of wheat straw fast pyrolysis vapors was studied as a

18 promising route for the production of renewable liquid transportation fuels. The performance of

$19 \mathrm{TiO}_{2}$-supported $\mathrm{Pt}\left(0.5\right.$ wt. \%) and $\mathrm{MoO}_{3}(10$ wt.\%) catalysts was compared to an industrial Mo-

20 based catalyst using a bench scale reactor operated at atmospheric pressure and up to high biomass-

21 to-catalyst ratios (B:C). Mass and energy balances were complemented by detailed bio-oil

22 characterization including advanced methods such as GC $\times$ GC-ToF/MS or-FID and ${ }^{13} \mathrm{C}$ NMR.

23 At 50 vol. $\% \mathrm{H}_{2}$, all three HDO catalysts effectively reduced the oxygen content of the bio-oils

24 to $\sim 7-12$ wt.\% (dry basis) compared to a non-catalytic reference (23 wt.\% O). $\mathrm{MoO}_{3} / \mathrm{TiO}_{2}$ was

25 least efficient in conversion of acids (TAN $=28 \mathrm{mg} / \mathrm{KOH}$ ), while $\mathrm{Pt} / \mathrm{TiO}_{2}$ and $\mathrm{MoO}_{3} / \mathrm{Al}_{2} \mathrm{O}_{3}$

26 obtained oils with TAN $\sim 13 \mathrm{mg} \mathrm{KOH} / \mathrm{g}$ (non-catalytic $=66 \mathrm{mg} \mathrm{KOH} / \mathrm{g}$ ). Compared to the $\mathrm{TiO}_{2-}$

27 supported catalysts, the industrial $\mathrm{Mo} / \mathrm{Al}_{2} \mathrm{O}_{3}$ catalyst produced higher yields of coke at the expense

28 of condensed bio-oil. $\mathrm{MoO}_{3} / \mathrm{TiO}_{2}$ performed similar to $\mathrm{Pt} / \mathrm{TiO}_{2}$ in terms of deoxygenation and

29 energy recovery of condensed bio-oil, and by increasing the $\mathrm{H}_{2}$ concentration to 90 vol.\% the

30 energy recovery of bio-oil increased to 39 and $42 \%$ at 8 and 10 wt. $\%$ O (d.b.), respectively. Pt/TiO 2

31 showed the highest selectivity to aliphatics and the lowest coke yields, e.g. the coke yield at B:C 8

32 was only 0.6 wt.\% of fed biomass.

33 This study demonstrates that by using low-pressures of hydrogen and appropriate HDO

34 catalysts, the quality of bio-oil can be improved without severely compromising its quantity

35 (carbon yield) as observed under catalytic fast pyrolysis conditions. 


\section{INTRODUCTION}

38 Fast pyrolysis of biomass is a well-developed technology, which can produce bio-oil at yields

39 up to $\sim 60 \mathrm{wt} . \%$ (water-free) [1-6]. The integration of biomass-derived pyrolysis oils in existing

40 oil refineries is a potential near-term solution for decreasing our dependence on crude oil and

41 increasing the share of renewables in the transportation sector [7-10]. However, the pyrolysis oil

42 has a high oxygen content of $\sim 35-50 \mathrm{wt} . \%$ (present as water and biomass-derived oxygenates),

43 resulting in several adverse properties such as low heating value, high polarity, acidity, and

44 instability upon storage and heating. The fuel properties and miscibility with fossil feedstock can

45 be improved via catalytic deoxygenation of the biomass pyrolysis vapors prior to their

46 condensation [10-19]. Though, these improvements come at the expense of carbon loss as light

47 hydrocarbons, $\mathrm{CO}, \mathrm{CO}_{2}$, and coke [20,21]. Amongst the variety of catalysts tested (without

48 hydrogen addition), microporous HZSM-5 zeolite is considered a suitable solid acid catalyst for

49 production of aromatics and gasoline range products from biomass-derived pyrolysis vapors

50 [22,23]. Nevertheless, rapid deactivation by coking is a major obstacle for their industrial

51 implementation [13,24].

52 Hydrodeoxygenation (HDO), on the other hand, uses hydrogen to selectively remove oxygen as

53 water without breaking the $\mathrm{C}-\mathrm{C}$ bonds, and therefore has the potential to obtain higher yields of

54 bio-oil with low oxygen content. Direct catalytic upgrading of biomass pyrolysis vapors by a dual

55 function 5 wt.\% $\mathrm{Ru} / \mathrm{TiO}_{2}$ catalyst was reported by Wan et al. [25], who evaluated $\mathrm{Ru} / \mathrm{TiO}_{2}$ in a

56 fixed-bed reactor for upgrading oak and switchgrass pyrolysis vapors at $400{ }^{\circ} \mathrm{C}$ and 0.58 bar $\mathrm{H}_{2}$.

$57 \mathrm{Ru} / \mathrm{TiO}_{2}$ showed a high ketonization activity and light oxygenates were converted to larger, less

58 oxygenated molecules, which improved the stability of the upgraded bio-oil. $\mathrm{The}^{\mathrm{TiO}} 2$ support is

59 known to be active for ketonization reactions of acids $\mathrm{TiO}_{2}[26-34]$ and the defunctionalization of

60 lignin-derived phenolics [35] without the need of hydrogen. As indicated by Wan et al. [25], the 
61 promotion of $\mathrm{TiO}_{2}$ with a noble metal ( $\mathrm{Ru}$ ) not only adds activity for (hydro-)deoxygenation, but

62 also plays a role in generating oxygen vacancy sites on the $\mathrm{TiO}_{2}$ surface which promote

63 deoxygenation via an oxygen-vacancy driven reverse Mars-van Krevelen process [36-39]. Using

$64 \mathrm{~m}$-cresol as a model compound for Pt supported $\mathrm{TiO}_{2}$, hydrogen spillover from the metal was

65 proposed to form Lewis-acidic oxygen vacancies on $\mathrm{TiO}_{2}$, which are capable of aryl-OH bond

66 scission [40]. Over $\mathrm{Pt}(111)$, ring hydrogenation to 3-methylcyclohexanone and 3-

67 methylcyclohexanol was found to be the most energetically favorable pathway, while over

$68 \mathrm{TiO}_{2}(101)$, tautomerization and direct deoxygenation to toluene were identified as additional

69 energetically favorable routes. Work conducted at NREL [41] demonstrated the use of 2 wt.\%

$70 \mathrm{Pt} / \mathrm{TiO}_{2}$ and $0.5 \mathrm{wt} . \% \mathrm{Pt} / \mathrm{TiO}_{2}$ for the continuous upgrading of pine FP vapors at bench-scale. The

71 presence of $\mathrm{Pt}$ enhanced the activity and/or prolonged the lifetime of $\mathrm{TiO}_{2}$ active sites under

72 reducing conditions. It was further proposed that Pt may prolong catalyst lifetime by facilitating

73 the removal of coke precursors from the catalyst surface. The catalytic activity of $2 \mathrm{wt} . \% \mathrm{Pt} / \mathrm{TiO}_{2}$

74 was found to be stable for 13 reaction/regeneration cycles (operated to biomass-to-catalyst (B:C)

75 ratio of $\sim 3$ ), and carbon recoveries of $38 \mathrm{C} \%$ with $\sim 16$ wt.\% oxygen (d.b.) were reported. This

76 level of deoxygenation allowed further processing of the condensed bio-oil by a single stage

77 hydrotreating. However, post-reaction characterization showed an increase in Pt particle size [41],

78 indicating irreversible catalyst deactivation through sintering.

79 Molybdenum trioxide $\left(\mathrm{MoO}_{3}\right)$ was found active for vapor-phase $\mathrm{HDO}$ of pyrolysis model

80 compounds and real biomass at low hydrogen pressures [42-45]. It has been reported that $\mathrm{MoO}_{3}$

81 undergoes partial carburization during reaction to from oxycarbide- and oxycarbohydride-

82 containing phases. This indicates that surface carbon plays an important role in the activity of

$83 \mathrm{MoO}_{3}$ under HDO conditions [44]. Studies conducted in the group of Román-Leshkov [43] found 
8410 wt. $\% \mathrm{MoO}_{3}$ dispersed on $\mathrm{ZrO}_{2}$ or $\mathrm{TiO}_{2}$ active and stable for the $\mathrm{HDO}$ of $\mathrm{m}$-cresol at $320{ }^{\circ} \mathrm{C}$

85 and low $\mathrm{H}_{2}$ pressures ( $\leq 1$ bar). The supported $\mathrm{MoO}_{3}$ catalysts selectively cleaved $\mathrm{C}-\mathrm{O}$ bonds

86 without saturating the aromatic ring, thus yielding toluene at moderate to high conversions. It was

87 found that the $\mathrm{ZrO}_{2}$ or $\mathrm{TiO}_{2}$ supports stabilized the active Mo species $\left(\mathrm{Mo}^{5+}\right)$ on the surface. While

88 hydrogen is crucial for retaining $\mathrm{HDO}$ activity in bulk $\mathrm{MoO}_{3}$, it can also change the speciation of

89 active species on the catalyst surface by over-reduction to lower oxidation states with lower

90 reactivity [42,46]. Murugappan et al. [47] tested 10 wt. $\% \mathrm{MoO}_{3} / \mathrm{TiO}_{2}$ and $\mathrm{MoO}_{3} / \mathrm{ZrO}_{2}$ at $500{ }^{\circ} \mathrm{C}$

91 and $\mathrm{H}_{2}$ pressures $\leq 0.75$ bar for $\mathrm{HDO}$ of pine FP vapors. The supported $\mathrm{MoO}_{3}(10$ wt. $\%)$ catalysts

92 achieved complete deoxygenation to olefinic and aromatic hydrocarbons at low biomass-to-

93 catalyst $(\mathrm{B}: \mathrm{C})$ ratios $<0.2$. Furans and phenols were found to increase until $\mathrm{B}: \mathrm{C} \sim 0.6$ before slowly

94 declining. For higher B:C ratios, the primary vapors were observed breaking through the catalyst

95 bed. The bare $\mathrm{TiO}_{2}$ support was reported to show minimal catalytic activity compared to

$96 \mathrm{MoO}_{3} / \mathrm{TiO}_{2}$ [47]. Others [48] reported a yield of $\sim 43 \mathrm{C} \% \mathrm{C}_{4}+$ hydrocarbons with $\sim 6$ wt. $\%$ oxygen

97 from upgrading of pine FP vapors in a fluidized bed with an industrial Mo based catalyst.

98 It is further important to note that the degree of deoxygenation (DOD) of pyrolysis vapors can

99 be enhanced by increasing the $\mathrm{H}_{2}$ partial pressure [42,48-50]. Higher $\mathrm{H}_{2}$ pressure can also lead to

100 increased hydrogenation of aromatic rings and olefins to their saturated counterparts. Techno-

101 economic analysis showed that for atmospheric HDO the catalyst cost (e.g. the noble metal

102 loading) and the biomass feedstock price are the primary contributors to the minimum selling price

103 of fuel obtained after hydrotreating [41]. Thus, it is important to consider these factors when

104 designing and testing catalysts for HDO. Since $\mathrm{MoO}_{3}$ is considerably cheaper than noble metals it

105 might be beneficial to use $\mathrm{MoO}_{3}$ based catalysts if similar catalytic performance can be achieved. 
107 biomass is fed into a fluidized catalyst bed (in-situ configuration [51,52]), or in a two-reactor 108 system in which the catalytic upgrading is performed in a separate reactor downstream of the 109 pyrolysis reactor (ex-situ configuration [52,53]). Compared to woody biomass, wheat straw 110 contains a much higher content of alkaline ashes such as $\mathrm{K}, \mathrm{Ca}, \mathrm{Cl}$ and $\mathrm{Mg}$. The direct contact with 111 the catalyst in an in-situ upgrading configuration can thus lead to transfer of the alkalines and 112 poisoning of catalytic sites [54-57]. In order to circumvent deposition of biomass indigenous ashes 113 on the catalyst and allow for determination of catalyst coking without the need of char separation, 114 the ex situ configuration was employed in this work.

115 Based on above research, in this work the deoxygenation performance of a $10 \mathrm{wt} . \% \mathrm{MoO}_{3} / \mathrm{TiO}_{2}$ 116 catalyst, an industrial Mo catalyst similar to that used in ref. [48], and a $0.5 \mathrm{wt} . \% \mathrm{Pt} / \mathrm{TiO}_{2}$ catalyst 117 were compared for the deoxygenation of wheat straw pyrolysis vapors in a continuous bench scale 118 unit. Mass and energy balances and a detailed analysis of the bio-oil properties allowed comparing 119 the performance of these $\mathrm{HDO}$ catalysts with frequently used solid acid catalysts such as $\gamma-\mathrm{Al}_{2} \mathrm{O}_{3}$ 120 and HZSM-5 zeolite. We investigated how the yield and the quality of bio-oil is influenced by the 121 amount of biomass pyrolysis vapors processed over the catalyst. Addressing this aspect will allow 122 determining the frequency of regeneration needed for maintaining a certain bio-oil quality in a 123 scenario of parallel fixed bed reactors [58]. We further studied to what extent the hydrogen 124 concentration influences the yield and quality of the bio-oil. In addition to commonly reported 125 characterization of bio-oils derived from woody biomass using GC-MS, elemental composition, 126 heating value and TAN, we conducted oil characterization by one- and two-dimensional ${ }^{13} \mathrm{C}$ and $127{ }^{1} \mathrm{H}$ NMR, GC $\times$ GC-ToF/MS or-FID, basic nitrogen determination, and thermogravimetric analysis 
128 in order to fully investigate the chemical composition and fuel properties of the bio-oils derived

129 from wheat straw FP vapors after atmospheric HDO.

\section{$130 \quad 2$ EXPERIMENTAL SECTION}

\section{$131 \quad 2.1 \quad$ Feedstock}

132 Wheat straw pellets were downsized to $<1.4 \mathrm{~mm}$ using a hammer mill. The proximate and

133 elemental analysis are shown in Table 1. Experimental details on the feedstock characterization

134 can be found in earlier work [13]. Potassium was amongst the highest concentrated ash

135 components with $\sim 1$ wt.\% (d.b.).

136 Table 1. Properties of wheat straw feedstock.

\begin{tabular}{|l|c|}
\hline Proximate analysis & \\
\hline Moisture (as received (a.r.)), & $8.8 \mathrm{wt.} \%$ \\
\hline Volatiles (dry basis, (d.b.) & $66.8 \mathrm{wt} . \%$ \\
\hline Fixed carbon (d.b., by diff.) & $18.5 \mathrm{wt} . \%$ \\
\hline Ash (d.b.) & $5.9 \mathrm{wt} . \%$ \\
\hline $\begin{array}{l}\text { Elemental composition (dry and } \\
\text { ash-free basis (daf)) }\end{array}$ \\
\hline Nitrogen \% & $0.8 \mathrm{wt} . \%$ \\
\hline Carbon \% & $50.4 \mathrm{wt} . \%$ \\
\hline Hydrogen \% & $5.6 \mathrm{wt} . \%$ \\
\hline Sulfur \% & $0.1 \mathrm{wt} \%$ \\
\hline Oxygen \% (by diff.) & $43.1 \mathrm{wt} . \%$ \\
\hline
\end{tabular}

$138 \quad 2.2$ Catalyst preparation

139 In order to achieve a high dispersion of Pt particles, $100 \mathrm{~g}$ of $\mathrm{Pt} / \mathrm{TiO}_{2}$ with a target $\mathrm{Pt}$ loading of

$140 \quad 0.5 \mathrm{wt} . \%$ was synthesized via strong electrostatic adsorption following the procedure described by

141 Griffin et al. and references therein $[41,59,60]$. The $\mathrm{pH}$ of an aqueous solution $(\sim 500 \mathrm{~mL}) \mathrm{of} 1 \mathrm{~g}$

142 of $\mathrm{Pt}\left(\mathrm{NH}_{3}\right)_{4}\left(\mathrm{NO}_{3}\right)_{2}$ was adjusted to 11.5 by adding $\mathrm{NH}_{4} \mathrm{OH}$. Titanium(IV) oxide, (Sigma Aldrich,

143 nanopowder, $21 \mathrm{~nm}$ primary particle size (TEM), $\geq 99.5 \%$ trace metals basis) was soaked for $24 \mathrm{~h}$

144 in the solution containing $5.7 \times 10^{-4} \mathrm{M}$ Pt. After impregnation, the catalyst suspension was dried at

145 room temperature for $48 \mathrm{~h}$ and then at $60{ }^{\circ} \mathrm{C}$ overnight. The catalyst was downsized to $250-850$

$146 \mu \mathrm{m}$ via pelletizing/crushing and filled into the catalytic reactor, where it was calcined/reduced in 
147 flowing $5 \% \mathrm{H}_{2} / \mathrm{N}_{2}$ at $450{ }^{\circ} \mathrm{C}$ for $5 \mathrm{~h}$. The catalyst was passivated in flowing $1 \% \mathrm{O}_{2} / \mathrm{N}_{2}$ at room 148 temperature before taking a sample for pre-reaction analysis.

$149100 \mathrm{~g}$ of $10 \mathrm{wt} . \% \mathrm{MoO}_{3} / \mathrm{TiO}_{2}$ was prepared via wet impregnation: Ammonium molybdate 150 tetrahydrate (Sigma-Aldrich, $99.98 \%$ trace metals basis) was dissolved in $80-160 \mathrm{~mL}$ nanopure 151 water and added to $10-20 \mathrm{~g}$ of $\mathrm{TiO}_{2}$ (Sigma Aldrich, nanopowder, $21 \mathrm{~nm}$ primary particle size 152 (TEM), $\geq 99.5 \%$ trace metals basis). The paste was mixed vigorously overnight using a magnetic 153 stirrer and then dried at $110{ }^{\circ} \mathrm{C}$ for $24 \mathrm{~h}$. The dried solid was transferred to a ceramic crucible and 154 calcined at $550{ }^{\circ} \mathrm{C}\left(10{ }^{\circ} \mathrm{C} / \mathrm{min}\right)$ for $4 \mathrm{~h}$ under static air. In addition, $100 \mathrm{~g}$ of bare $\mathrm{TiO}_{2}$ support 155 (same as for preparation of $\mathrm{MoO}_{3} / \mathrm{TiO}_{2}$ and $\mathrm{Pt} / \mathrm{TiO}_{2}$ ) was prepared after calcination at the same 156 conditions used for preparation of $\mathrm{MoO}_{3} / \mathrm{TiO}_{2}$. Prior to reaction tests, all catalysts were reduced 157 for $2 \mathrm{~h}$ at $450{ }^{\circ} \mathrm{C}$ under reaction atmosphere $\left(50\right.$ or 90 vol. $\left.\% \mathrm{H}_{2}\right)$.

\section{$158 \quad 2.3$ Catalyst characterization}

159 The Mo loading of the $\mathrm{MoO}_{3} / \mathrm{TiO}_{2}$ catalyst was determined by $\mathrm{X}$-ray fluorescence (XRF)

160 following the procedure described in earlier work [13]. For the quantification of Ti and $\mathrm{Pt}$ in the

$161 \mathrm{Pt} / \mathrm{TiO}_{2}$ catalyst, 0.1-0.15 g finely ground sample was weighed accurately and transferred 162 quantitatively into a Teflon microwave digestion vessel in duplicate. $9 \mathrm{ml}$ of $37 \% \mathrm{HCl}$ (p.a. 163 quality), $3 \mathrm{ml}$ of $65 \% \mathrm{HNO}_{3}$ (p.a. quality) and $2 \mathrm{ml}$ of $47-51 \% \mathrm{HF}$ (p.a. quality) were added and 164 the sample was digested at $200{ }^{\circ} \mathrm{C}$ for 20 minutes in a Milestone Ethos UP microwave digestion 165 unit yielding a clear sample solution. The sample solution was then transferred to a $100 \mathrm{ml}$ 166 volumetric flask and filled to the mark with pure water (18.2 M $\Omega)$. The contents of Ti and Pt in 167 the sample solution were quantified by Inductively Coupled Plasma-Optical Emission 168 Spectrometry (ICP-OES) with an Agilent 720 ES ICP-OES instrument. The sample was analyzed 169 with suitable dilution and the emission signal from several Ti and Pt specific emission lines were 
170 compared to the signal from certified calibration standards containing $0-10 \mathrm{mg} / \mathrm{l}$ for Ti and 0

$1712.5 \mathrm{mg} / \mathrm{l}$ for Pt. The precision of the analysis was $\pm 3 \%$ relative with $95 \%$ confidence.

172 For analysis of the $\mathrm{Pt} / \mathrm{TiO}_{2}$ catalyst by transmission electron microscopy (TEM), the catalyst

173 was ground in a mortar and sieved to $<50 \mu \mathrm{m}$ before adding them on a copper TEM grid with lacey

174 carbon film. TEM images were acquired using a Tecnai T20 G2 (at an acceleration voltage of

$175200 \mathrm{kV}$ ). For acquisition of X-ray diffraction (XRD) patterns, samples were analyzed in powder

176 form using a zero background holder on a Siemens D500 x-ray diffractometer operated with MDI

177 Datascan software. A copper x-ray tube operating at $45 \mathrm{kV}$ and $30 \mathrm{~mA}$ was used in combination

178 with a Ni filter, 0.3 degree divergence and anti-scatter slits, and a 0.15 degree detector slit. A

179 graphite monochromater was tuned to the $\mathrm{Cu}$ K-alpha line. Samples were scanned from 10 to 70

180 degrees two-theta with a step size of 0.05 degrees and a dwell time of 2 seconds per step. The

181 patterns were processed using Jade software version 9.5 from MDI.

$182 \mathrm{~N}_{2}$ physisorption was carried out on a Quantachrome Novatouch apparatus at liquid nitrogen

183 temperature. Prior to the measurement, the samples were outgassed under vacuum at $350{ }^{\circ} \mathrm{C}$

184 overnight. The specific surface area $\left(S_{\mathrm{BET}}\right)$ was calculated by the Brunauer-Emmett-Teller (BET)

185 method. The total pore volume $\left(V_{\text {total }}\right)$ was calculated from the amount of adsorbed nitrogen at the

186 relative pressure of $p / p_{0}=0.99$. The Barrett-Joyner-Halenda $(\mathrm{BJH})$ pore size distribution was

187 derived from the adsorption branch of the $\mathrm{N}_{2}$ physisorption isotherm.

188 Temperature programmed desorption (TPD) of ammonia was conducted for the characterization 189 and quantification of the catalyst's acid sites. The measurements were performed using a 190 Micromeritics Autochem II 2920 Chemisorption analyzer. The samples were first heated to $500{ }^{\circ} \mathrm{C}$ 191 at $20^{\circ} \mathrm{C} / \mathrm{min}$ in $20 \mathrm{~mL} / \mathrm{min} \mathrm{He}$ and held for $1 \mathrm{~h}$ to remove moisture. Next, the sample temperature 192 was decreased to $450{ }^{\circ} \mathrm{C}$, and the catalyst was reduced in a $10 \mathrm{vol} . \% \mathrm{H}_{2} / \mathrm{He}$ mixture for $2 \mathrm{~h}$ at the 
193 same flowrate. Then, the temperature was lowered to $100{ }^{\circ} \mathrm{C}$ and $\mathrm{NH}_{3}$ was adsorbed for 30 min by

194 flowing 10 vol.\% $\mathrm{NH}_{3} / \mathrm{He}$ at $20 \mathrm{~mL} / \mathrm{min}$. Any weakly adsorbed $\mathrm{NH}_{3}$ was purged with $\mathrm{He}$ for 60

$195 \mathrm{~min}$ at $20 \mathrm{ml} / \mathrm{min}$. The sample was then heated to $500{ }^{\circ} \mathrm{C}$ at $10{ }^{\circ} \mathrm{C} / \mathrm{min}$ under the same flow

196 conditions and the $\mathrm{NH}_{3}$ desorption was recorded using a thermal conductivity detector (TCD).

197 Diffuse reflectance infrared Fourier transform spectroscopy (DRIFT) of pyridine-loaded

198 samples was performed following the procedure reported previously [61] with the modification

199 that the catalyst was reduced at $450{ }^{\circ} \mathrm{C}$ for $1 \mathrm{~h}$ in a flow of $10 \% \mathrm{H}_{2} / \mathrm{N}_{2}$ before cooling the sample

200 to $150{ }^{\circ} \mathrm{C}$ for acquisition of the spectra of the reduced catalyst. The flow was then changed to argon

201 and pyridine was adsorbed on the reduced catalysts from the vapor phase for 30 min using a

202 bubbler operated at room temperature. After flushing any weakly adsorbed pyridine for 30 min,

203 the spectra of the pyridinated sample was acquired. Absorbance from 4000 to $400 \mathrm{~cm}^{-1}$ was

204 collected using 64 scans at a $4 \mathrm{~cm}^{-1}$ resolution. A background spectrum was recorded with pure $205 \mathrm{KBr}$ at $150{ }^{\circ} \mathrm{C}$.

\subsection{Pyrolysis unit}

207 A detailed description of the bench scale fast pyrolysis unit is found in earlier work [13], and a

208 flow sheet is provided in Fig. S1. In this work, tests were conducted in either 50 vol.\% or 90 vol.\%

209 hydrogen (balance nitrogen) at a total flowrate of $\sim 8.7 \mathrm{N1} / \mathrm{min}$ and a maximum operating pressure

210 of $\sim 0.1$ bar above atmosphere. The biomass feeding-rate on a dry and ash-free basis (daf) was

$211 \sim 3 \mathrm{~g} / \mathrm{min}$. The pyrolysis reactor, the cyclones, and the hot gas filter were externally heated to

$212530{ }^{\circ} \mathrm{C}, 450{ }^{\circ} \mathrm{C}$, and $350{ }^{\circ} \mathrm{C}$, respectively. In earlier work [62], the experimental uncertainty in

213 terms of \pm 2 standard deviations for the yields of gas, organic liquid, reaction water, and char was

214 estimated to $2.1 \mathrm{wt} . \%, 0.4 \mathrm{wt} . \%, 0.8 \mathrm{wt} . \%$ and $3.8 \mathrm{wt} . \%$, respectively. In this work, a catalyst mass

215 of $100 \mathrm{~g}$ was used and the typical duration of the assays was $\sim 2 \mathrm{~h}$ for tests run to $\mathrm{B}: \mathrm{C} \sim 4$ and $\sim 4 \mathrm{~h}$

216 for tests run to $\mathrm{B}: \mathrm{C} \sim 8$. A catalytic upgrading temperature of $450{ }^{\circ} \mathrm{C}$ was found optimal by Wang 
217 et al. [48] for the industrial $\mathrm{Mo} / \mathrm{Al}_{2} \mathrm{O}_{3}$ catalyst, and the same temperature was employed here for

218 the tests with $\mathrm{MoO}_{3} / \mathrm{TiO}_{2}$. For catalytic upgrading with $\mathrm{Pt} / \mathrm{TiO}_{2}$, the reactor was heated to $400{ }^{\circ} \mathrm{C}$,

219 which has been reported to avoid condensation of the pyrolysis vapors while higher temperatures

220 are undesirable due to a decrease in hydrogen coverage and thermodynamic limitations on ring

221 hydrogenation, which inhibit HDO reaction pathways [41]. Upon contact with the vapors, the

222 temperature of the catalyst (measured in the middle of the fixed bed) increased by $\sim 25-50{ }^{\circ} \mathrm{C}$

223 within the first $\sim 15$ min of biomass feeding (B:C $\sim 0.5$ ), after which the bed temperature slowly

224 decreased while remaining $5-25^{\circ} \mathrm{C}$ above its set point temperature (see Fig. S2). Condensation

225 was achieved by a three-stage condensation system consisting of i) a condensation stage at $4{ }^{\circ} \mathrm{C}$,

226 ii) an electrostatic precipitator (ESP) for collection of aerosols that were generated during the initial

227 quench, and iii) a condensation stage at $-60{ }^{\circ} \mathrm{C}$ consisting of a series of impingers immersed in a

228 dry-ice/EtOH bath. The dry gas was analyzed continuously for $\mathrm{CO}$ and $\mathrm{CO}_{2}$ by nondispersive

229 infrared and $\mathrm{O}_{2}$ by paramagnetism, and every $\sim 10$ min a sample was analyzed by GC-FID/TCD

230 for analysis of $\mathrm{C}_{1}-\mathrm{C}_{6}$ hydrocarbons and $\mathrm{H}_{2}$.

$231 \quad 2.5$ Oil characterization

232 Each experiment yielded five different liquid fractions, which were kept refrigerated at $5{ }^{\circ} \mathrm{C}$ in

233 order to minimize ageing reactions. Liquid collected at the $4{ }^{\circ} \mathrm{C}$ condensation stage and the $-60{ }^{\circ} \mathrm{C}$

234 condensation stage spontaneously phase separated into an aqueous and organic-rich phase, while

235 a single-phase organic-rich oil was collected at the ESP. The three oil fractions and the two

236 aqueous fractions were combined in the proportion of their yields for further analysis. The moisture

237 content and elemental content ( $\mathrm{CHN}$, O by difference) of the total bio-oil and aqueous phase was

238 determined by Karl-Fischer titration and elemental analysis according to the details described

239 elsewhere [13]. The higher heating value of the bio-oil (d.b.) was calculated based on the elemental 
240 composition using an empirical formula according to Channiwala and Parikh [63]:

$241 H H V\left[\mathrm{MJ} / \mathrm{kg}_{\text {d.b. }}\right]=0.3491 \times$ wt. $\% \mathrm{C}+1.1783 \times$ wt. $\% \mathrm{H}-0.1034 \times$ wt. $\% \mathrm{O}-0.0151 \times$ wt. $\% \mathrm{~N}$.

242 The oil and aqueous fractions were analyzed using a GC-MS/FID Shimadzu QP 2010 Ultra

243 apparatus equipped with a Supelco Equity 5 column. Identification and quantification of the

244 species in the samples were performed by the mass spectrometer (MS) and flame ionization

245 detector (FID), respectively. Aqueous samples were analyzed directly while the oil samples were

246 diluted in a 1:9 volumetric ratio in acetone. The initial temperature for the GC column was held at

$24740{ }^{\circ} \mathrm{C}$ for $10 \mathrm{~min}$ and the column was heated to $250{ }^{\circ} \mathrm{C}$ with an initial heating rate of $2{ }^{\circ} \mathrm{C} / \mathrm{min}$ to

$248100{ }^{\circ} \mathrm{C}$ followed by an increased heating rate of $8{ }^{\circ} \mathrm{C} / \mathrm{min}$. A split ratio of 80 was used at the

249 injection port $\left(280{ }^{\circ} \mathrm{C}\right)$. The MS scanning was set to a range of 20 to $300 \mathrm{~m} / \mathrm{z}$. The selectivity of

250 different product groups was calculated based on the FID area percentage after correcting the FID

251 areas taking into account the effective carbon numbers of each compound as outlined by

252 Schofield [64]: Selectivity product group $=\frac{\sum \text { FID areas of compounds in product group }}{\sum \text { FID areas of all compounds }} \times 100 \%$.

253 The condensed oil fractions were further analyzed for their total acid number (TAN) following

254 ASTM D664, and for their basic nitrogen content following UOP Method 269-10. Using the 255 methodology reported by Dayton and coworkers [65,66], the evaporation behavior of the oils was

256 studied by thermogravimetric analysis (TGA). About $20 \mathrm{mg}$ of oil was loaded into a Pt crucible

257 with lid shortly before start of the temperature program in order to minimize the loss of volatiles.

258 The temperature was increased at a rate of $10^{\circ} \mathrm{C} / \mathrm{min}$ to a final temperature of $650{ }^{\circ} \mathrm{C}$ in 150 $259 \mathrm{ml} / \mathrm{min} \mathrm{N}_{2}$ flow.

260 Bio-oil samples obtained in the 50 vol. $\% \mathrm{H}_{2}$ atmosphere without catalyst and at $\mathrm{B}: \mathrm{C} \sim 4$ from 261 atmospheric HDO with the three different catalysts were further characterized by $262 \mathrm{GC} \times \mathrm{GC}-\mathrm{ToF} / \mathrm{MS}$ or-FID. In addition, bio-oil obtained from vapor upgrading with $\mathrm{MoO}_{3} / \mathrm{TiO}_{2}$ at 
263 an increased $\mathrm{H}_{2}$ partial pressure $\left(90\right.$ vol.\%) was analyzed. For the analysis, a LECO ${ }^{\circledR}$ Pegasus 264 4DTM instrument was used that included an Agilent 7890A GC equipped with a Gerstel ${ }^{\circledR}$ CIS 4 265 PTV inlet, a secondary oven, a quad-jet, dual-stage cryogenic-based (liquid $\mathrm{N}_{2}$ ) modulator, a time266 of-flight (ToF) mass spectrometer (MS) and a flame ionization detector (FID). The primary (1D) 267 and secondary (2D) columns were Restek ${ }^{\circledR}$ Rtx-1701 and SGE® BPX5, respectively. $0.3 \mathrm{~mm}^{3}$ 268 sample, diluted 1:1 in THF, was injected in pulsed split mode (split ratio 1:100) into the PVT inlet 269 at $40{ }^{\circ} \mathrm{C}$, and then raised to $300{ }^{\circ} \mathrm{C}\left(10^{\circ} \mathrm{C} / \mathrm{s}\right)$, with a total hold up time of $1.5 \mathrm{~min}$. The main oven 270 with the $1 \mathrm{D}$ column was held at $35^{\circ} \mathrm{C}$ for $1.5 \mathrm{~min}$ and then ramped to $275{ }^{\circ} \mathrm{C}$ at $3{ }^{\circ} \mathrm{C} / \mathrm{min}$; the 271 secondary oven and modulator were run with offsets to the main oven of $+10{ }^{\circ} \mathrm{C}$ and $+25{ }^{\circ} \mathrm{C}$, 272 respectively; total run time was $101.5 \mathrm{~min}$. Helium (He) was used as carrier gas at constant flow 273 rate of $1.5 \mathrm{~cm}^{3} / \mathrm{min}$, and the modulation period was $7 \mathrm{sec}$. The transfer line and ion source of the $274 \mathrm{ToF} / \mathrm{MS}$ detector were operated at constant temperatures of $250{ }^{\circ} \mathrm{C}$ and $225^{\circ} \mathrm{C}$, respectively. The $275 \mathrm{ToF} / \mathrm{MS}$ was run in EI mode at $70 \mathrm{eV}$ and an acquisition rate of $100 \mathrm{spectra} / \mathrm{sec}$ for $\mathrm{m} / \mathrm{z}=41$ to 276 441. The NIST2008 mass spectral database was used as reference. For group quantification, the 277 FID was used. The detector was operated at $300^{\circ} \mathrm{C}$ and with a sampling rate of $100 \mathrm{~Hz}$. Based on 278 the $\mathrm{GC} \times \mathrm{GC}-\mathrm{ToF} / \mathrm{MS}$ analysis the compounds were classified into 13 groups: aliphatics 279 (paraffins/naphthenes), monoaromatics (alkylbenzenes/naphthenobenzenes), di/tri-aromatics, 280 carboxylic acids, pyrroles/nitriles, pentanones/hexanones, furanones/furfuryl alcohols, aliphatic 281 ketone/other aliphatic oxygenates, indanones/benzofurans/dibenzofuranes, 282 phenols/methoxybenzenes, methoxy-phenols, hydroxylated di/tri-aromatics, and dihydroxylated 283 benzenes. The relative amount (FID area-\%) of each compound class was estimated as the sum of 284 areas of all detected peaks in that class divided by the total peak area of all compound classes. 285 ChromaTof ${ }^{\circledR} 4.72 \mathrm{GC} \times \mathrm{GC}$ software was applied for data acquisition and exporting of raw data as 
CDF files. Successively, pixel-based analysis (proprietary software developed by Copenhagen

287 University) of CDF files was applied for setting up group integration templates and quantification

288 of relative amounts (area-\%) of compound classes.

289 Selected bio-oils were further analyzed by ${ }^{1} \mathrm{H},{ }^{13} \mathrm{C}$ NMR and 2D HSQC NMR analysis. Details

290 of the used instruments and experimental conditions have been reported earlier [13]. The

291 quantitative ${ }^{13} \mathrm{C}$ integration was performed following the procedure suggested by Ben and

292 Ragauskas [67], while taking into account the modifications suggested by Happs et al. [68]. For

$293{ }^{1} \mathrm{H}$ NMR, the relative distribution of the different chemical groups was obtained by assigning the

294 functional groups to their chemical shift ranges. The water region (3.6-3.3 ppm) was excluded for 295 this comparison.

2963 RESULTS AND DISCUSSION

$297 \quad 3.1$ Catalyst properties

298 The catalyst properties are shown in Table 2. The metal loading of the $\mathrm{TiO}_{2}$-supported $\mathrm{Pt}$ and

299 Mo catalysts was determined to be $0.61 \mathrm{wt} . \%$ Pt and $5.8 \mathrm{wt} \%$ Mo (theoretical loading of 10 wt.\%

$300 \mathrm{MoO}_{3}=6.7$ wt. $\%$ Mo). The XRD pattern of the fresh prepared $\mathrm{MoO}_{3} / \mathrm{TiO}_{2}$ catalyst closely

301 resembles the pattern of the bare $\mathrm{TiO}_{2}$ support (see Fig. S3), indicating that the $\mathrm{MoO}_{3}$ is well

302 dispersed on the support. Only few minor additional peaks are observed at $2 \theta=23.3^{\circ}, 33.6^{\circ}$, and

$30349.2^{\circ}$, which are associated with crystalline $\mathrm{MoO}_{3}$ clusters [47]. The isotherms and pore size

304 distribution obtained from nitrogen physisorption are shown in Fig. $\mathrm{S} 4$ for the $\mathrm{Pt} / \mathrm{TiO}_{2}$ and

$305 \mathrm{MoO}_{3} / \mathrm{TiO}_{2}$ catalyst. $\mathrm{MoO}_{3} / \mathrm{TiO}_{2}$ showed a reduced pore volume $(0.23 \mathrm{cc} / \mathrm{g})$ compared to $\mathrm{Pt} / \mathrm{TiO}_{2}$

$306(0.43 \mathrm{cc} / \mathrm{g})$, probably due to the higher loading of the Mo compared to Pt. The pore size distribution

307 by the $\mathrm{BJH}$ suggests that $\mathrm{MoO}_{3} / \mathrm{TiO}_{2}$ has less pores with diameter $>400 \AA$ compared to $\mathrm{Pt} / \mathrm{TiO} 2$

308 (see Fig. S4b). Since the crystal size is about $21 \mathrm{~nm}(210 \AA)$, these larger pores were attributed to

309 voids in between adjacent crystals. The BET surface area of $\mathrm{Pt} / \mathrm{TiO}_{2}$ was $51 \mathrm{~m}^{2} / \mathrm{g}$ while that of 
$310 \mathrm{MoO}_{3} / \mathrm{TiO}_{2}$ was $54 \mathrm{~m}^{2} / \mathrm{g}$. A surface area of $54 \mathrm{~m}^{2} / \mathrm{g}$ was also determined by Shetty et al. [43] for

311 a 10 wt. $\% \mathrm{MoO}_{3} / \mathrm{TiO}_{2}$ catalyst . Amongst the tested catalysts, the industrial $\mathrm{Mo} / \mathrm{Al}_{2} \mathrm{O}_{3}$ catalyst had

312 the highest acidity with $0.5 \mathrm{mmol} \mathrm{NH}_{3} / \mathrm{g}$, which is about double the acidity of the $\mathrm{Pt} / \mathrm{TiO}_{2}$ and $\sim 2.5$

313 times the acidity of the $\mathrm{MoO}_{3} / \mathrm{TiO}_{2}$ catalyst.

314 The $\mathrm{NH}_{3}$-TPD in Fig. S5 shows that the reduced $\mathrm{Pt} / \mathrm{TiO}_{2}$ catalyst had both weak acid sites

315 desorbing $\mathrm{NH}_{3}$ at $\sim 180{ }^{\circ} \mathrm{C}$ and medium-strength acid sites desorbing $\mathrm{NH}_{3}$ at $\sim 300{ }^{\circ} \mathrm{C}$. $\mathrm{TiO}_{2-}$

316 supported $\mathrm{MoO}_{3}$ catalyst showed mostly weak acid sites centered at a desorption peak of $\sim 200{ }^{\circ} \mathrm{C}$

317 and to a lesser extent medium strength acid sites, resulting in a lower acidity compared to

$318 \mathrm{Pt} / \mathrm{TiO}_{2}$ (see Table 2).

319 The catalysts are Lewis acidic as seen by interaction with pyridine at 1612 and $1445 \mathrm{~cm}^{-1}$ (see

320 Fig. S6) and the absence of absorbance at $1545 \mathrm{~cm}^{-1}$ (pyridine adsorbed on Brønsted acid). At

$321150{ }^{\circ} \mathrm{C} \mathrm{MoO}_{3} / \mathrm{TiO}_{2}$ showed a higher absorbance of pyridinated Lewis acid sites compared to

$322 \mathrm{Pt} / \mathrm{TiO}_{2}$. Since pyridine is a weaker base than ammonia, it will preferably probe medium- to high-

323 strength acid sites. From $\mathrm{NH}_{3}$-TPD (Fig. S5) it can be seen that $\mathrm{Pt} / \mathrm{TiO}_{2}$ contains a relative higher

324 fraction of medium-strength acid sites compared to $\mathrm{MoO}_{3} / \mathrm{TiO}_{2}$. For both samples, the

325 chemisorbed pyridine readily desorbed when heated from $150{ }^{\circ} \mathrm{C}$ to $250{ }^{\circ} \mathrm{C}$.

326 Table 2. Physicochemical properties of $\mathrm{TiO}_{2}$ supported $\mathrm{Pt}\left(0.5\right.$ wt.\%) and $\mathrm{MoO}_{3}(10$ wt.\%)

327 catalysts.

\begin{tabular}{|l|c|c|c|c|}
\hline & $\mathrm{TiO}_{2}$ & 0.5 wt.\% Pt/TiO & $\begin{array}{c}10 \mathrm{wt} \% \\
\mathrm{MoO}_{3} / \mathrm{TiO}_{2}\end{array}$ & $\mathrm{Mo}_{2} \mathrm{Al}_{2} \mathrm{O}_{3}$ \\
\hline Metal loading & n.d. & 0.61 & $5.8^{\mathrm{b})}$ & n.d. \\
\hline$V_{\text {total }}$ at $\mathrm{p} / \mathrm{p}_{0}=0.99(\mathrm{cc} / \mathrm{g})$ & 0.38 & 0.43 & 0.23 & n.d. \\
\hline Surface area $\left[\mathrm{m}^{2} / \mathrm{g}\right]$ & 47 & 51 & 54 & n.d. \\
\hline Acidity ${ }^{\mathrm{a})}\left[\mathrm{mmol} \mathrm{NH}_{3} / \mathrm{g}\right]$ & 0.16 & 0.25 & 0.19 & 0.50 \\
\hline
\end{tabular}

$328{ }^{\text {a) }}$ The acidity was determined for the reduced catalysts (reduction for $2 \mathrm{~h}$ in $10 \mathrm{vol} . \% \mathrm{H}_{2}$ ); ${ }^{\text {b) }}$ loading 329 of molybdenum

330 Representative TEM images of the prepared $\mathrm{Pt} / \mathrm{TiO}_{2}$ catalyst are provided in Fig. S7. The Pt 331 particles were well dispersed on the $\mathrm{TiO}_{2}$ support with particle diameters between 0.4 and $3.3 \mathrm{~nm}$ 
332 and a mean particle diameter of 1.65 (determined for 110 particles). A Pt particle size distribution

333 between 0-5 $\mathrm{nm}$ diameter has also been reported by others for a $2 \mathrm{wt} . \% \mathrm{Pt} / \mathrm{TiO}_{2}$ catalyst [69], albeit

334 their work also showed larger particles $>5 \mathrm{~nm}$, which may be related to the higher Pt loading.

335

336

337

338

339

340

341

342

343

344

345

346

347

348

349

350

351

352

353

354

355

\subsection{Product distribution}

The product distribution obtained from atmospheric pressure catalytic HDO in comparison to two non-catalytic reference cases obtained under inert atmosphere $\left(\mathrm{N}_{2}\right)$ and 50 vol. $\% \mathrm{H}_{2}$ are shown in Fig. 1. The numeric values are given in Table $\mathrm{S} 1$ and Table $\mathrm{S} 2$ for tests conducted in 50 and 90 vol.\% $\mathrm{H}_{2}$, respectively. For reference, the product distributions obtained with an empty catalytic reactor and over $100 \mathrm{~g} \mathrm{TiO}_{2}$ at $450{ }^{\circ} \mathrm{C}$ under nitrogen atmosphere are given in Table $\mathrm{S} 3$, and the properties of the respective bio-oils are given in Table S4. Mass balances between 90-98\% were obtained. Upgrading of the vapors over $\mathrm{TiO}_{2}$ under nitrogen atmosphere at $\mathrm{B}: \mathrm{C} \sim 4$ increased the formation of light gases, reaction water, and coke while decreasing the yield of condensed organics recovered as oil and aqueous phase (see Table S3). Similarly, the yield of light gases and reaction water increased when applying catalytic $\mathrm{HDO}$, which can be attributed to cracking reactions $\left(\mathrm{C}_{1^{-}}\right.$ $\mathrm{C}_{5}$ hydrocarbons), and deoxygenation via decarbonylation, decarboxylation, and hydrodeoxygenation. The yields of gas and coke were higher at low B:C ratios, at the expense of liquid-range organics. With continued operation to higher B:C, the yields of gas and coke decreased due to a reduced catalyst activity, and the yield of condensed organics increased. The aqueous phase obtained without catalyst under $\mathrm{N}_{2}$ atmosphere contained an appreciable amount of organics ( 11 wt.\% of fed biomass), which decreased to $8 \mathrm{wt} . \%$ of fed biomass when the test was performed in 50 vol. $\% \mathrm{H}_{2}$ while obtaining a slightly higher yield of oil phase. This observation is tentatively attributed to a low degree of hydrodeoxygenation of the most reactive vapor compounds via contact of the vapors with i) the metal surface of the pyrolysis reactor/cyclones/catalytic reactor and ii) the vapor contact with biomass indigenous alkalines and metals both during the pyrolysis 
and upon vapor contact with the char. The slight deoxygenation can lower the polarity of the oxygenates and thus decrease the loss of organics to the aqueous phase.

358 Atmospheric $\mathrm{HDO}$ using $\mathrm{Pt} / \mathrm{TiO}_{2}$ decreased the yield of liquid-range organics and increased the 359 yields of light gases, reaction water, and coke. Operation to higher B:C shifted the yields in the 360 direction of the non-catalytic reference and further increased the yield of condensed organics. 361 Remarkably low coke yields resulted for $\mathrm{Pt} / \mathrm{TiO}_{2}$ toward higher $\mathrm{B}: \mathrm{C}$, which will be discussed more 362 in section 3.4. Increased $\mathrm{H}_{2}$ partial pressure led to an enhanced gas production for $\mathrm{Pt} / \mathrm{TiO}_{2}$ and $363 \mathrm{MoO}_{3} / \mathrm{TiO}_{2}$, and increased the yield of reaction water for the latter while no marked increase in 364 hydrodeoxygenation was observed for $\mathrm{Pt} / \mathrm{TiO}_{2} \cdot \mathrm{Mo} / \mathrm{Al}_{2} \mathrm{O}_{3}$ produced less liquid-range organics and 365 more coke compared to $\mathrm{Pt} / \mathrm{TiO}_{2}$ at $\mathrm{B}: \mathrm{C} \sim 4$. The yield of ethylene and propylene was the highest 366 for $\mathrm{Mo} / \mathrm{Al}_{2} \mathrm{O}_{3}\left(1.5\right.$ wt-\%) compared to $\mathrm{Pt} / \mathrm{TiO}_{2}(0.9 \mathrm{wt}-\%)$ and $\mathrm{MoO}_{3} / \mathrm{TiO}_{2}(1.0 \mathrm{wt}-\%)$. It is known 367 that for $\mathrm{HDO}$ of acetone over $\mathrm{MoO}_{3}$, the oxygen is removed while making propene [42]. On the 368 other hand, the yield of $\mathrm{C}_{1}-\mathrm{C}_{3}$ alkanes was slightly higher for $\mathrm{Pt} / \mathrm{TiO}_{2}$, which is attributed to the $\mathrm{Pt}$ 369 catalyzed hydrogenation of some of the alkenes and oxygenates [70]. The initial deactivation when 370 using $\mathrm{Pt} / \mathrm{TiO}_{2}$ also corresponded to a decrease in the concentration of $\mathrm{C}_{2}-\mathrm{C}_{5}$ alkanes and an 371 increase in the $\mathrm{C}_{2}-\mathrm{C}_{5}$ alkene concentration (see Fig. S8). The loss of hydrogenation activity may 372 be associated with the blocking of metallic Pt sites, and is in line with observations by Griffin et 373 al. [41]. Besides a lower hydrogenation activity of the $\mathrm{Mo} / \mathrm{Al}_{2} \mathrm{O}_{3}$ catalyst compared to $\mathrm{Pt} / \mathrm{TiO}_{2}$, it 374 is expected that the $\mathrm{Al}_{2} \mathrm{O}_{3}$ supported catalyst has a higher surface area and in combination with its 375 significantly higher acidity $\left(0.5 \mathrm{mmol} \mathrm{NH}_{3} / \mathrm{g}\right)$, catalytic cracking is favored. This can explain the 376 higher coke and lower oil yields observed for the vapor upgrading over $\mathrm{Mo} / \mathrm{Al}_{2} \mathrm{O}_{3}$ compared to the $377 \mathrm{TiO}_{2}$-based catalysts. Slightly more reaction water and less $\mathrm{CO} / \mathrm{CO}_{2}$ was formed with $\mathrm{Mo} / \mathrm{Al}_{2} \mathrm{O}_{3}$ 378 compared to $\mathrm{Pt} / \mathrm{TiO}_{2}$. In 50 vol. $\% \mathrm{H}_{2}, \mathrm{MoO}_{3} / \mathrm{TiO}_{2}$ produced the lowest gas yields and highest yield 
379 of liquid-range organics at $\mathrm{B}: \mathrm{C} \sim 4$. The yield of coke and reaction water for $\mathrm{MoO}_{3} / \mathrm{TiO}_{2}$ was in 380 between the values for $\mathrm{Pt} / \mathrm{TiO}_{2}$ and $\mathrm{MoO}_{3} / \mathrm{Al}_{2} \mathrm{O}_{3}$ (Fig. 1). An increase in $\mathrm{H}_{2}$ concentration in the 381 gas (from 50 vol.\% to 90 vol.\%) increased the yield of light gases and reaction water due to 382 increased hydrodeoxygenation and slightly decreased the coke yield (from 1.7 wt.\% to 1.6 wt.\% 383 of biomass). The yield of organic oil phase was similar for 90 and $50 \%$ vol. $\% \mathrm{H}_{2}$, but less organics 384 were recovered in the aqueous stream when using 90 vol.\% $\mathrm{H}_{2}$. This is attributed to a reduced 385 polarity of oxygenates, as will be elaborated in more detail in section 3.3. For $\mathrm{MoO}_{3} / \mathrm{TiO}_{2}$, the 386 operation to higher biomass-to-catalyst ratio (7.3 vs. 3.6) decreased the yields of gas, reaction 387 water, and coke while the yield of liquid range organics increased. However, this increase was 388 largely due to a higher fraction of organics recovered in the aqueous stream (from 2.2 wt.\% to 3.7 389 wt.\% of biomass).

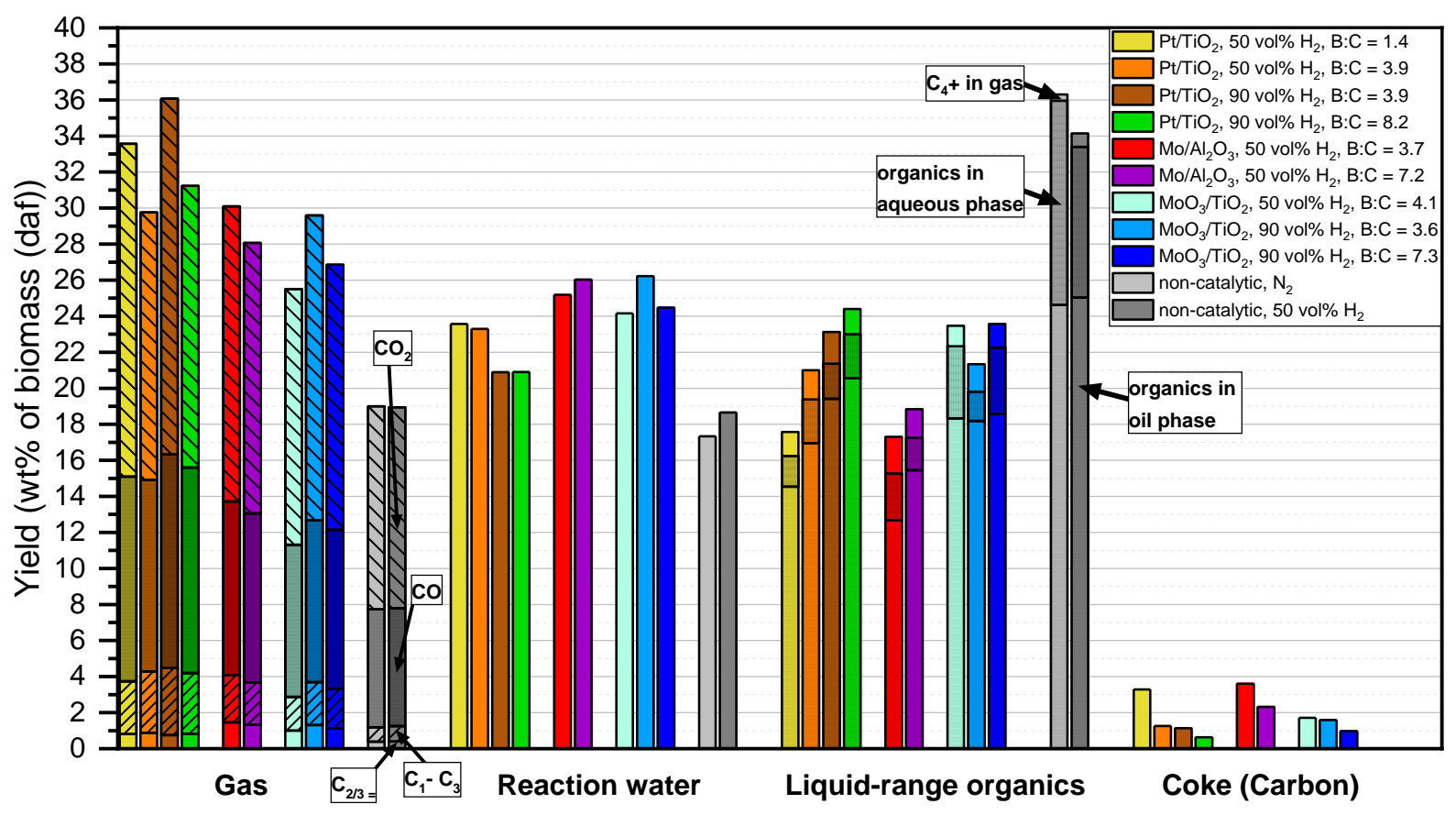

391 Fig. 1. Product yields based on fed biomass (daf). The char yield was $19.2 \pm 0.8 \mathrm{wt} . \%$, with the uncertainty 392 being related to the manual collection process. 

415 (empty reactor) to $77-83 \mathrm{wt} . \%$ upon use of catalyst, while the oxygen content was reduced from 416

\subsection{Bio-oil properties}

Table 3 presents an overview of the bio-oil properties along with the B:C ratio at which the oil was obtained and the experimental conditions such as catalyst temperature and $\mathrm{H}_{2}$ concentration.

Under $\mathrm{N}_{2}$ atmosphere, the vapor treatment with bare $\mathrm{TiO}_{2}$ reduced the oxygen content from $\sim 27$ wt. $\%$ O (d.b.) to $\sim 20 \mathrm{wt} . \%$, which increased the $\mathrm{HHV}$ from $\sim 28$ to $31 \mathrm{MJ} / \mathrm{kg}$. The use of $\mathrm{TiO}_{2}$ under inert atmosphere reduced the total acid number (TAN) of the bio-oil from 71 to $43 \mathrm{mg}$ $\mathrm{KOH} / \mathrm{g}$ (see Table S4), which is attributed to mild cracking and ketonization reactions [26-32]. The oil obtained without catalyst in 50 vol. $\% \mathrm{H}_{2}$ showed an oxygen content of 23 wt. $\% \mathrm{O}$ (d.b.). Catalytic $\mathrm{HDO}$ in 50 vol.\% $\mathrm{H}_{2}$ to $\mathrm{B}: \mathrm{C} \sim 4$ achieved a clear reduction in the acidity of the bio-oils since the TAN was decreased from $66 \mathrm{mg} \mathrm{KOH} / \mathrm{g}$ to $12-13 \mathrm{mg} \mathrm{KOH} / \mathrm{g}$ when using $\mathrm{Pt} / \mathrm{TiO}_{2}$ and $\mathrm{Mo} / \mathrm{Al}_{2} \mathrm{O}_{3}$ while it was decreased to $28 \mathrm{mg} \mathrm{KOH} / \mathrm{g}$ when using $\mathrm{MoO}_{3} / \mathrm{TiO}_{2}$. The results indicate that both a high hydrogenation/HDO activity $\left(\mathrm{Pt} / \mathrm{TiO}_{2}\right)$ and a high acidity $\left(\mathrm{Mo} / \mathrm{Al}_{2} \mathrm{O}_{3}\right)$ can effectively convert acids, whereas the poorer performance of $\mathrm{MoO}_{3} / \mathrm{TiO}_{2}$ in TAN-reductionalthough still improved compared to the bare $\mathrm{TiO}_{2}$-likely results from its lower hydrogenation/HDO activity and lower catalyst acidity.

It is known that not only carboxylic acids but also phenolic compounds contribute to TAN, e.g. the acid number for phenol is $\sim 10 \mathrm{mg}$ of $\mathrm{KOH} / \mathrm{g}$ [15]. The TAN could be further decreased by increasing the $\mathrm{H}_{2}$ partial pressure, as shown for $\mathrm{MoO}_{3} / \mathrm{TiO}_{2}$ and $\mathrm{Pt} / \mathrm{TiO}_{2}$, thereby reaching values as low as $2 \mathrm{mg} \mathrm{KOH} / \mathrm{g}$ at $\mathrm{B}: \mathrm{C} \sim 4$ in the case of $\mathrm{Pt} / \mathrm{TiO}_{2}$, which is the same range as acidic crude oils [71]. At 50 vol. $\% \mathrm{H}_{2}$ and $\mathrm{B}: \mathrm{C} \sim 4$, the $\mathrm{MoO}_{3} / \mathrm{TiO}_{2}$ catalyst achieved similar deoxygenation compared to $\mathrm{Pt} / \mathrm{TiO}_{2}$ and $\mathrm{Mo} / \mathrm{Al}_{2} \mathrm{O}_{3}$. The moisture content of the bio-oils was reduced from 19 wt.\% to 2-7 wt. $\%$ after catalytic upgrading. The carbon content of the oils increased from $70 \mathrm{wt} . \%$ 23 wt. \% to 7-12 wt.\%. While complete deoxygenation was not obtained at low B:C $\sim 4$, the oxygen 
417 content remained fairly stable and did not significantly increase towards higher B:C, unlike acidic 418 catalysts such as HZSM-5 or $\gamma-\mathrm{Al}_{2} \mathrm{O}_{3}$ where usually a rapid deactivation is observed [13,14,62]. A 419 slight deterioration in the oil-properties was observed when comparing the oils obtained at B:C $~ 4$ 420 and $\mathrm{B}: \mathrm{C} \sim 7$ or 8 at the same $\mathrm{H}_{2}$ concentration, since the TAN and the oxygen content of the oils 421 increased while the revaporization efficiency decreased (Table 3). This slight decrease in activity 422 is attributed to the continuous coke build-up rather than a permanent deterioration in the 423 deoxygenation capacity. A stable deoxygenation performance for a $\mathrm{TiO}_{2}$ supported $\mathrm{Pt}$ catalyst 424 during 13 reaction/regeneration cycles was reported by Griffin et al. [41].

425 The catalytic treatment increased the HHV of the bio-oils from $\sim 28 \mathrm{MJ} / \mathrm{kg}$ to $\sim 36-38 \mathrm{MJ} / \mathrm{kg}$. 426 The effective hydrogen index (EHI) as defined by Chen et al. is a calculated indicator of the 'net' $427 \mathrm{H} / \mathrm{C}$ ratio of a feed after debiting the feed's hydrogen content for complete conversion of 428 heteroatoms to $\mathrm{NH}_{3}, \mathrm{H}_{2} \mathrm{~S}$, and $\mathrm{H}_{2} \mathrm{O}$, according to $E H I=\frac{H-2 O-3 N-2 S}{C}$ [72]. Compounds or 429 mixtures with EHI's <1 led to rapid catalyst coking when upgraded over a ZSM-5 catalyst. Higher 430 EHI's of bio-oils may therefore limit the coking when further processing the bio-oil by fluid 431 catalytic cracking (FCC) units. The atmospheric HDO treatment increased the effective hydrogen 432 index (EHI) from $\sim 0.3$ to $\sim 1.0$ (Table 3). The increase in $\mathrm{H}_{2}$ concentration from 50 to 90 vol.\% 433 increased the EHI of the oils obtained using $\mathrm{MoO}_{3} / \mathrm{TiO}_{2}$ from 0.95 to 1.09 , while the EHI of the 434 oils obtained by vapor treatment with $\mathrm{Pt} / \mathrm{TiO}_{2}$ remained in the range of 1.05 . The trend in EHI 435 correlates with the trends in molar $\mathrm{H} / \mathrm{C}$ ratio, as both parameters are indicative of the hydrogen 436 incorporation, e.g., via hydrogenation of olefins and aromatic rings.

437 The basic nitrogen content of bio-oils is an important parameter for the processing of the 438 upgraded bio-oils in a FCC unit of a conventional refinery since basic nitrogen compounds 439 (reversibly) poison the FCC catalysts via rapid coking and the combustion of nitrogen containing 
440 coke species requires nitrous oxide abatement. The vapor treatment with the HDO catalyst did not

441 markedly affect the basic nitrogen content of the bio-oils compared to the non-catalytic reference

442 (0.4 mass\%), and it is known that basic heterocyclic compounds, e.g. pyridines and quinolones are

443 among the most difficult to remove via hydrodenitrification [73]. While some denitrification may

444 have been achieved, the decrease in oil yield (especially at lower B:C) may have led to a

445 concentration of more recalcitrant basic nitrogen species.

446 The volatility and stability of the oils obtained from atmospheric HDO improved significantly

447 upon catalytic treatment, as seen from the weight loss curves during heating of the oils in a TGA

448 (see Fig. S9-S11), The revaporization efficiency $[65,66]$ stated in Table 3 indicates what fraction

449 of the (water-free) oil had volatized at $350{ }^{\circ} \mathrm{C}$. The revaporization efficiency increased from $\sim 70 \%$

450 to $86-96 \%$ by applying atmospheric vapor $\mathrm{HDO}$. Oils obtained using $\mathrm{Pt} / \mathrm{TiO}_{2}$ for vapor $\mathrm{HDO}$

451 showed the highest revaporization efficiency ( 95\%). At B:C 4 and 50 vol.\% $\mathrm{H}_{2}$, amongst the

452 three $\mathrm{HDO}$ catalysts the revaporization efficiency of bio-oil obtained using the $\mathrm{MoO}_{3} / \mathrm{TiO}_{2}$ catalyst

453 was the lowest (86\%). However, the revaporization efficiency of bio-oils obtained from vapor

454 upgrading with $\mathrm{MoO}_{3} / \mathrm{TiO}_{2}$ catalysts improved when increasing the hydrogen concentration to

45590 vol.\% $\mathrm{H}_{2}$. As such, the reduced reactivity and charring tendency of the oils correlates with

456 increased $\mathrm{EHI}$ and $\mathrm{H} / \mathrm{C}$ ratios, which is reasonable since alkanes have a higher volatility and are

457 less reactive compared to (unsaturated) oxygenated compounds. 
460 Table 3. Properties of phase-separated bio-oil fraction for catalysts $(100 \mathrm{~g})$ and reaction conditions as 461 indicated

\begin{tabular}{|c|c|c|c|c|c|c|c|c|c|c|}
\hline Catalyst & - & \multicolumn{4}{|c|}{$\mathrm{Pt} / \mathrm{TiO}_{2}$} & \multicolumn{2}{|c|}{$\mathrm{Mo} / \mathrm{Al}_{2} \mathrm{O}_{3}$} & \multicolumn{3}{|c|}{$\mathrm{MoO}_{3} / \mathrm{TiO}_{2}$} \\
\hline $\begin{array}{l}\text { Reactor } \\
\text { temperature }\end{array}$ & $\begin{array}{c}500 \\
{ }^{\circ} \mathrm{C}\end{array}$ & \multicolumn{4}{|c|}{$400{ }^{\circ} \mathrm{C}$} & \multicolumn{2}{|c|}{$450{ }^{\circ} \mathrm{C}$} & \multicolumn{3}{|c|}{$450{ }^{\circ} \mathrm{C}$} \\
\hline $\mathrm{H}_{2}$ vol. $\%$ & 50 & 50 & 50 & 90 & 90 & 50 & 50 & 50 & 90 & 90 \\
\hline $\mathrm{B}: \mathrm{C}$ & - & 1.4 & 3.9 & 3.9 & 8.2 & 3.7 & 7.2 & 4.1 & 3.6 & 7.3 \\
\hline $\begin{array}{l}\text { Yield of oil phase } \\
\text { [wt-\% (daf)] }\end{array}$ & 25.0 & 15.8 & 17.0 & 19.4 & 20.6 & 12.7 & 17.3 & 18.3 & 18.2 & 18.6 \\
\hline $\begin{array}{l}\text { Energy recovery oil } \\
+\mathrm{C}_{4}+\end{array}$ & 37.2 & 31.5 & 36.1 & 41.6 & 42.3 & 28.9 & 32.4 & 36.6 & 39.1 & 38.1 \\
\hline $\mathrm{H}_{2} \mathrm{O}$ content $[\%]$ & 18.7 & 7.0 & 2.7 & 2.6 & 5.0 & 1.8 & 2.8 & 4.6 & 2.8 & 4.3 \\
\hline wt-\% N (d.b.) & 1.1 & 1.7 & 2.3 & 2.9 & 2.0 & 2.8 & 2.8 & 2.9 & 2.7 & 2.4 \\
\hline wt-\% C (d.b.) & 70.3 & 83.0 & 78.0 & 78.6 & 78.2 & 78.5 & 77.2 & 78.2 & 80.4 & 78.8 \\
\hline wt-\% H (d.b.) & 5.2 & 8.2 & 8.8 & 8.7 & 8.8 & 8.7 & 8.5 & 8.2 & 8.9 & 8.5 \\
\hline wt-\% O (d.b.) & 23.4 & 7.0 & 10.9 & 9.8 & 11.0 & 9.9 & 11.5 & 10.7 & 8.0 & 10.3 \\
\hline $\begin{array}{l}\text { Higher heating } \\
\text { value }(\mathrm{HHV}) \\
{[\mathrm{MJ} / \mathrm{kg}]}\end{array}$ & 28.2 & 37.9 & 36.4 & 36.7 & 36.5 & 36.6 & 35.8 & 35.8 & 37.7 & 36.5 \\
\hline $\begin{array}{l}\text { Effective hydrogen } \\
\text { index }\end{array}$ & 0.34 & 1.00 & 1.05 & 1.04 & 1.07 & 1.04 & 1.00 & 0.95 & 1.09 & 1.02 \\
\hline $\mathrm{H} / \mathrm{C}$ & 0.88 & 1.18 & 1.34 & 1.32 & 1.34 & 1.32 & 1.31 & 1.25 & 1.32 & 1.29 \\
\hline $\mathrm{O} / \mathrm{C}$ & 0.25 & 0.06 & 0.11 & 0.09 & 0.11 & 0.09 & 0.11 & 0.10 & 0.07 & 0.10 \\
\hline TAN [mg KOH/g] & 66 & 13 & 12 & 2 & 12 & 13 & 19 & 28 & 13 & 20 \\
\hline $\begin{array}{l}\text { Basic nitrogen } \\
\text { (mass-\%) }\end{array}$ & 0.40 & 0.52 & 0.39 & 0.49 & 0.38 & 0.37 & 0.34 & 0.37 & 0.36 & 0.38 \\
\hline $\begin{array}{l}\text { revaporization } \\
\text { efficiency @350 }{ }^{\circ} \mathrm{C} \\
\text { (\% d.b.) }\end{array}$ & 70 & 95 & 96 & 96 & 95 & 94 & 91 & 86 & 92 & 90 \\
\hline
\end{tabular}

463 The relative abundance of the main compound groups detected by GC-MS/FID in the phase

464 separated aqueous fractions is shown in Fig. 2a. After atmospheric HDO, the aqueous phase

465 organics that could be detected by GC-FID were mainly comprised of phenolics, acids, ketones,

466 and alcohols (see Fig. 2a). The aqueous phase from the non-catalytic reference contained less

467 phenolics and more ester, methoxy-phenol, and (anhydro-)sugar-type compounds. Fig. 2c shows

468 the semi-quantitative yields by multiplying the yield of total organics (d.b.) in the aqueous phase

469 with the selectivity of identified compounds. The atmospheric HDO clearly reduced the yield of

470 acids recovered in the aqueous phase. The yield of acids contained in the aqueous phase increased 
471 towards higher $\mathrm{B}: \mathrm{C}$, and at similar $\mathrm{B}: \mathrm{C}$ it decreased when increasing the $\mathrm{H}_{2}$ concentration. These

472 trends correlate with the TAN of the phase-separated bio-oil fraction (see Table 3), and the same

473 observations have been reported for the upgrading of wheat straw FP vapors with solid acid

474 catalysts in $\mathrm{N}_{2}$ atmosphere [14]. Since acids are difficult to hydrogenate they are likely

475 decarbonylated or converted via ketonization, which can explain a high yield of 2-butanone

476 (ketonization product of acetic acid and propionic acid) and 2-pentanone (ketonization of two 477 propionic acid molecules) observed in the oil phase (see Fig. 3).

478 The selectivity and yields of compounds in the oil phase as detected by GC-MS/FID is shown 479 in Fig. $2 c+d$. Compared with the non-catalytic reference, the oils obtained from atmospheric HDO 480 contained higher concentrations of hydrocarbons such as aliphatics and monoaromatics, and higher 481 concentrations of phenolics while methoxy-phenols and acids were effectively reduced or even 482 converted completely. Note that the ketonization of acetic acid over $\mathrm{TiO}_{2}$ would yield acetone 483 [74], which was used as solvent and therefore excluded in the analysis of the oil-phase. The acetone 484 formed from ketonization of acetic acid was likely to some extent converted to propane/propene, 485 in agreement with increased yields of propane/propene compared to the non-catalytic reference. 486 The increase in $\mathrm{H}_{2}$ partial pressure from 50 to 90 vol.\% increased the yield of hydrocarbons, and $487 \mathrm{Pt} / \mathrm{TiO}_{2}$ was more selective to aliphatics while $\mathrm{MoO}_{3} / \mathrm{TiO}_{2}$ did not favor ring hydrogenation and 488 favored monoaromatics. The chromatograms of the non-catalytic reference oil (50 vol.\% $\left.\mathrm{H}_{2}\right)$ and 489 two oils obtained after $\mathrm{HDO}$ with $\mathrm{Pt} / \mathrm{TiO}_{2}$ and $\mathrm{MoO}_{3} / \mathrm{TiO}_{2}$ catalysts at $\mathrm{B}: \mathrm{C} \sim 4\left(90\right.$ vol. $\left.\% \mathrm{H}_{2}\right)$ are 490 shown in Fig. 3. Interestingly, the alkanes obtained with $\mathrm{Pt} / \mathrm{TiO}_{2}$ at 90 vol.\% comprised long chain 491 alkanes such pentadecane, heptadecane, and eicosane, which indicates the occurrence of C-C 492 coupling reactions, possibly via ketonization and subsequent alkylation or aldol condensation with 493 other light oxygenates [25]. The highest yield of aliphatics was 1.7 wt.\% of fed biomass. Griffin 
494 et al. [41] found that the concentration of unreacted oxygenates such as acetic acid and

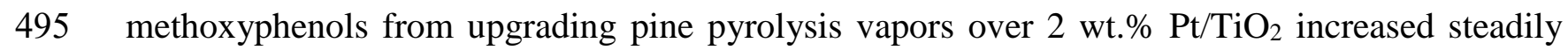
496 during the course of the reaction to B:C $\sim 3$. The analysis of their condensed oil by GC-MS showed 497 a high concentration of phenols and ketones, which agrees with this work; however, a higher 498 concentration of methoxyphenols was reported in Griffin et al.'s work [41]. This is likely related 499 to the higher lignin content of pine compared to wheat straw and the higher oxygen content of the 500 upgraded bio-oil ( 16 wt.\%, d.b.) reported by Griffin et al. [41] compared to this work (7-11 wt.\% 501 O, d.b). In agreement with our observations (Fig. 3), Wan et al. [25] reported significant decrease 502 in acetic acid, hydroxyacetone, methoxy-phenols and dihydrobenzofuran when upgrading fast 503 pyrolysis vapors from oak and switchgrass with 5 wt. $\% \mathrm{Ru} / \mathrm{TiO}_{2}$ at $400{ }^{\circ} \mathrm{C}\left(0.6\right.$ bar $\left.\mathrm{H}_{2}\right)$, while an 504 increase in acetone, 2-butanone, 2-cyclopenten-1-one, and phenol was observed. The effective 505 conversion of methoxyphenols from wheat straw fast pyrolysis vapors by HDO using the industrial $506 \mathrm{Mo} / \mathrm{Al}_{2} \mathrm{O}_{3}$ agrees with Wang et al.'s [48] results for upgrading pine fast pyrolysis vapors (in-situ 507 reactor configuration). Based on the high selectivity to phenols (Fig. 2c) after atmospheric HDO, 508 phenols are likely an important contributor to the TAN of the upgraded bio-oils [15]. Since the 509 breakage of phenolic $\mathrm{C}-\mathrm{O}$ bonds requires a high bond dissociation energy of $468 \mathrm{~kJ} / \mathrm{mol}$ [75], we 510 hypothesize that only the increased hydrodeoxygenation activity at increased $\mathrm{H}_{2}$ partial pressure 511 allowed to further decrease the yield of phenolics and therefore reduced the TAN of the bio-oils 512 (see Table 3). 


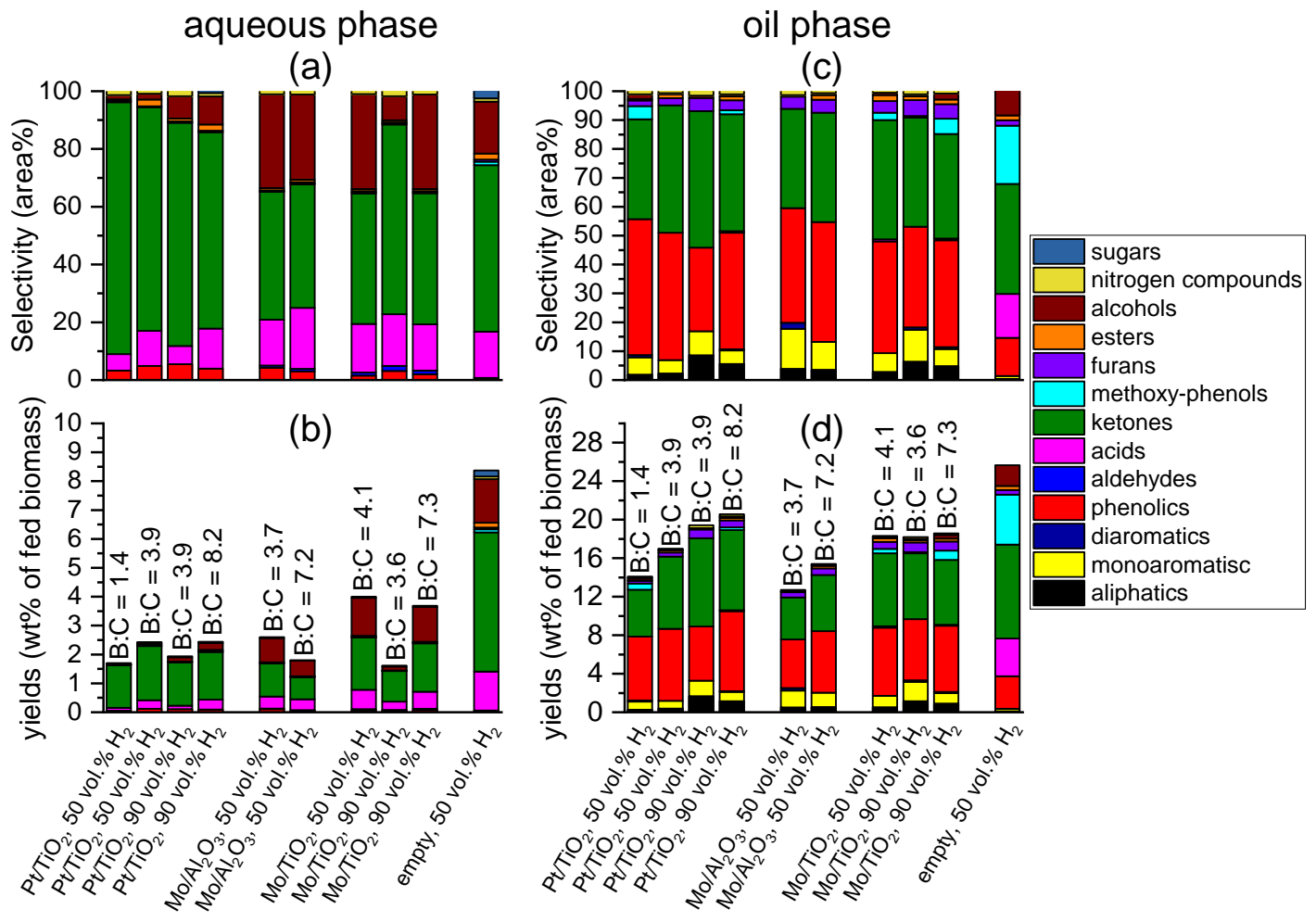

Fig. 2. GC-MS/FID results: (a) Selectivity of compounds (grouped) in aqueous phase. (b) Semi-quantitative 515 yields of compounds in aqueous phase. (c) Selectivity of compounds (grouped) in oil phase. (d) Semi516 quantitative yields of compounds in oil phase. 


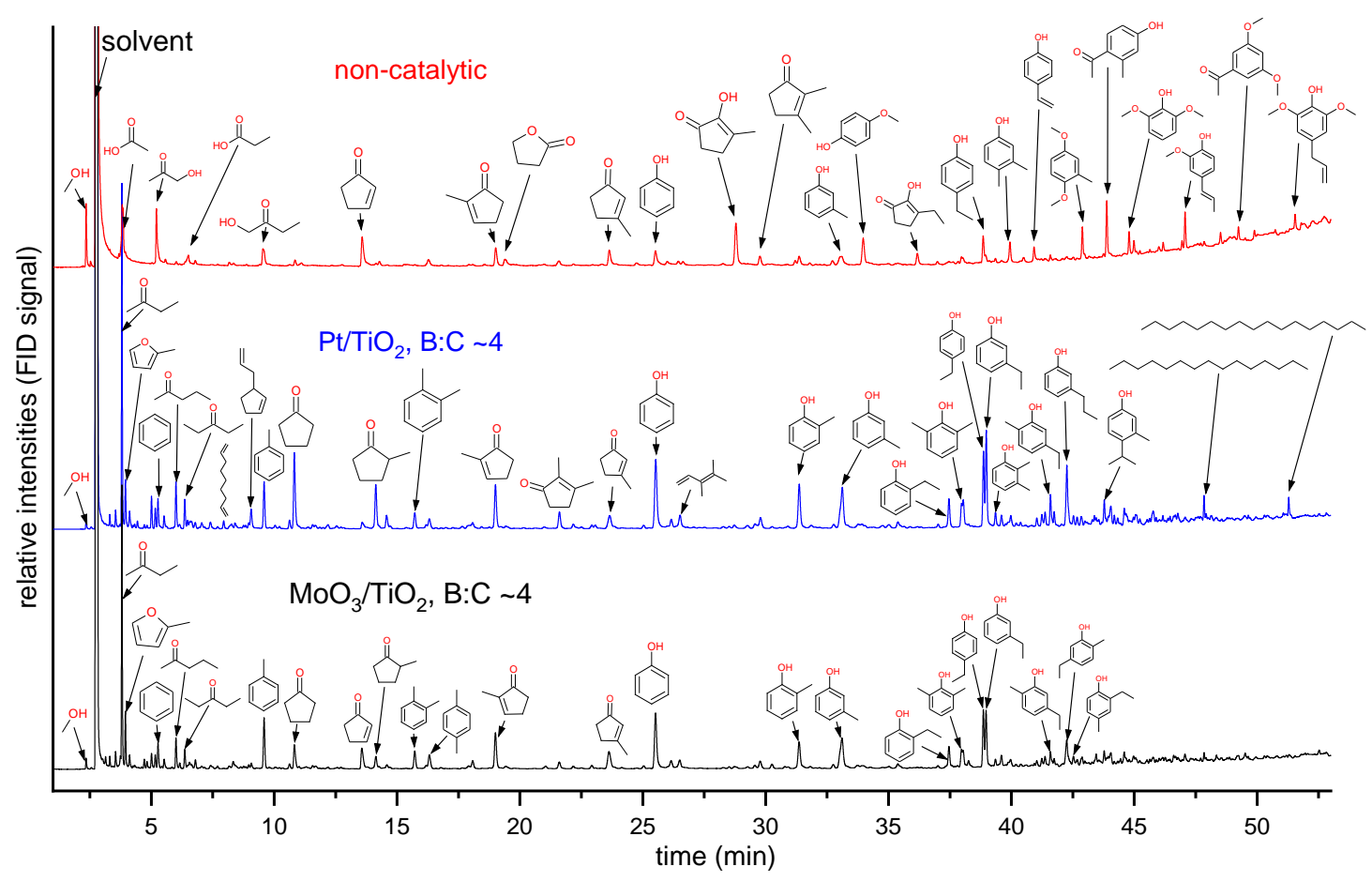

518 Fig. 3. GC-FID chromatograms of non-catalytic reference $\left(50\right.$ vol. $\left.\% \mathrm{H}_{2}\right)$ and two oils obtained after HDO 519 with $\mathrm{Pt} / \mathrm{TiO}_{2}$ and $\mathrm{MoO}_{3} / \mathrm{TiO}_{2}$ catalyst at $\mathrm{B}: \mathrm{C} \sim 4\left(90\right.$ vol.\% $\left.\mathrm{H}_{2}\right)$.

520 Two-dimensional GC $\times$ GC analysis allows characterizing the bio-oil comprehensively based on

521 the spatial separation of polar and nonpolar compounds, thereby expanding the range of volatile 522 compounds that can be analyzed. The 2D GC $\times$ GC plots for the non-catalytic oil and oils obtained 523 at $\mathrm{B}: \mathrm{C} \sim 4$ and 50 vol.\% $\mathrm{H}_{2}$ using the three different catalysts are shown in Fig. S12-S16. In 524 addition, the oil obtained from vapor upgrading with $\mathrm{MoO}_{3} / \mathrm{TiO}_{2}$ at $\mathrm{B}: \mathrm{C} \sim 4$ and 90 vol.\% $\mathrm{H}_{2}$ was 525 analyzed to demonstrate the effect of $\mathrm{H}_{2}$ partial pressure on the oil composition. The integration 526 results of the different regions in the two-dimensional plots are summarized in Fig. 4. Note that 527 the contribution of acids (Ac), nitrogen containing groups (Nit), and furanones/furfuryl alcohols 528 (Fur) was multiplied by 10 for better visibility. Most noticeably, the GC $\times$ GC analysis shows a 529 severe reduction in the yield of Ac, Nit, pentanones/hexanones, Fur, dihydroxylated benzenes, and 530 methoxy-phenols after vapor HDO compared to the non-catalytic reference, in general agreement 531 with the decrease in oxygen content and TAN. On the other the hand, the yield of oxygen-free 
532 hydrocarbons, especially aromatics increased after HDO. The contribution of acids, ketones (Ket),

533 furans, phenols $(\mathrm{Ph})$, and methoxy-phenols $(\mathrm{MeO}-\mathrm{Ph})$ was lowest for the industrial Mo catalyst,

534 while this catalyst showed the highest aromatics content. This observation agrees with both the

535 GC-MS/FID results (Fig. 2) and the NMR characterization of the bio-oils (Table 4 and Table 5).

536 The $\mathrm{Pt} / \mathrm{TiO}_{2}$ catalyst was most selective to phenolics, in agreement with the trends suggested by

537 GC-MS/FID (Fig. 2). An increase in the $\mathrm{H}_{2}$ concentration from 50 to 90 vol.\% led to a clear

538 improvement in the bio-oil properties as shown for $\mathrm{MoO}_{3} / \mathrm{TiO}_{2}$. The selectivity to oxygen-free

539 hydrocarbons (Ali + Ar) increased at the expense of oxygen-containing compound groups. This

540 observation agrees with the findings by GC-MS/FID (Fig. 2) and a reduction in oxygen content

541 and TAN (see Table 3).

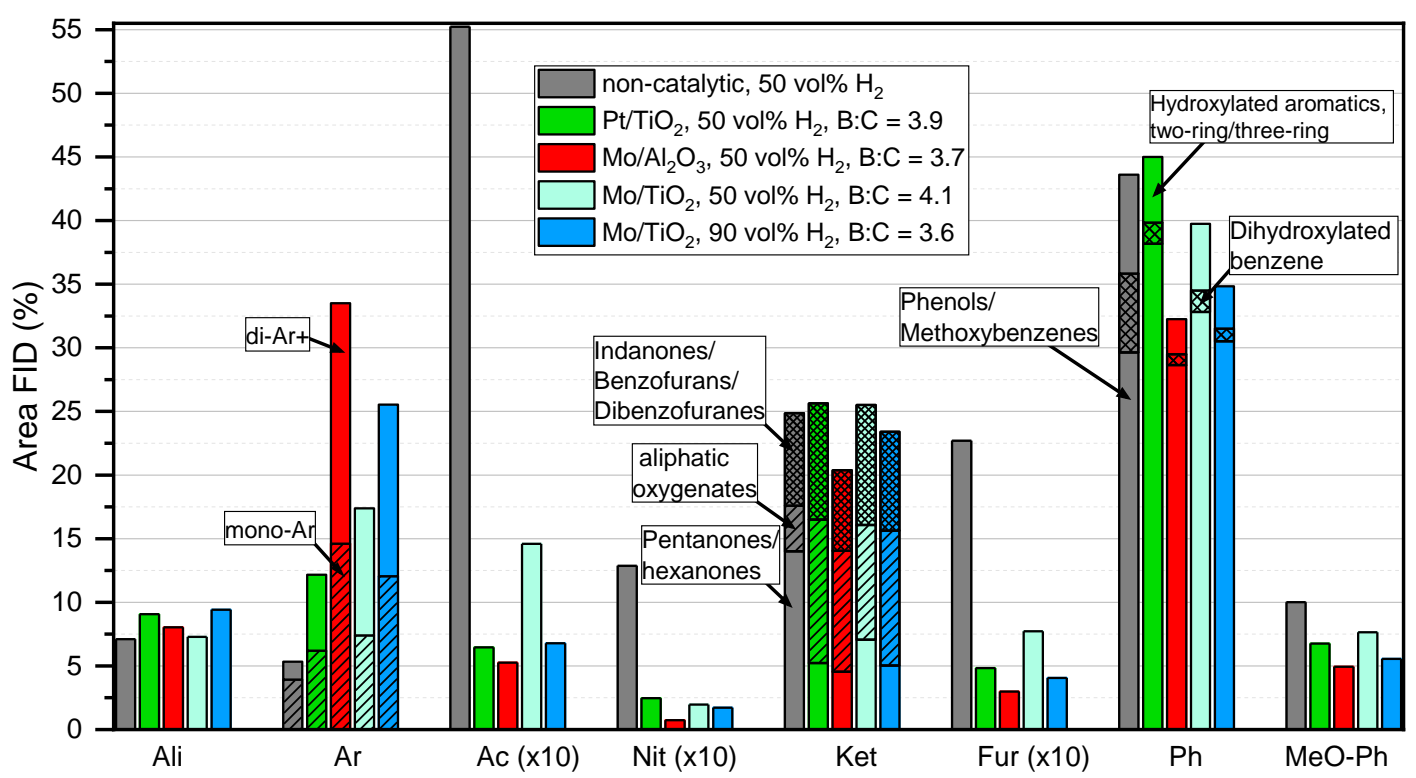

543 Fig. 4. GC $\times$ GC-FID analysis of the bio-oils. The components in the condensed organics are divided into 544 aliphatics (Ali), aromatics (mono and di+ Ar), acids (Ac), pyrroles/nitriles (Nit), ketones (Ket), 545 furanones/furfuryl alcohols (fur), phenols $(\mathrm{Ph})$, and methoxy-phenols. The relative FID area contribution 546 of Ac, Nit and Fur was multiplied by 10 for better visibility.

547 While gas chromatography methods provide single-compound information, only the fraction 548 volatilizing during injection $\left(\sim 280^{\circ} \mathrm{C}\right)$ is analyzed. Compounds with higher boiling point, light 549 compounds overlapping with the solvent (acetone), or reactive compounds that oligomerize or 
550 form char during the injection are not analyzed. The heating of the oils in the TGA (Fig. S9-S11)

551 indicates that only $56 \mathrm{wt} . \%$ of the organics (water-free) volatilized at the injection temperature for

552 the non-catalytic reference oil, while $\sim 83-86$ wt. $\%, 82-85$ wt. $\%$, and $\sim 74-83$ wt. $\%$ of the upgraded

553 oils volatilized when using $\mathrm{Pt} / \mathrm{TiO}_{2}, \mathrm{Mo} / \mathrm{Al}_{2} \mathrm{O}_{3}$, and $\mathrm{MoO}_{3} / \mathrm{TiO}_{2}$, respectively.

554 In order to obtain information on the whole composition of the bio-oils, the non-catalytic bio555 oil and the bio-oils obtained from atmospheric $\mathrm{HDO}$ with the three different catalysts at $\mathrm{B}: \mathrm{C} \sim 4$ in 55650 vol.\% were analyzed by ${ }^{13} \mathrm{C}$ and ${ }^{1} \mathrm{H}$ NMR. The spectra are provided in Fig. S17-S18 while 557 Table 4 and Table 5 summarize the contribution of different product groups according to their 558 chemical shift range. The atmospheric HDO reduced the contribution of carbonyls from $\sim 15 \%$ to $559 \sim 8-10 \%$ and the contribution of aromatic $\mathrm{C}-\mathrm{O}$ was reduced from $\sim 13$ to $7-9 \%$ (Table 4). The HDO 560 resulted in a clear decrease of aliphatic $\mathrm{C}-\mathrm{O}$ groups from $\sim 10$ to $\sim 2 \%$, and methoxyl groups were 561 practically removed completely (detection level). While the aromatic $\mathrm{C}-\mathrm{C}$ and $\mathrm{C}-\mathrm{H}$ regions overlap 562 to some extent, the sum of aromatic $\mathrm{C}-\mathrm{C}$ and $\mathrm{C}-\mathrm{H}$ contributions clearly increased by the catalytic 563 treatment from $\sim 26 \%$ to $\sim 32-33 \%$ using $\mathrm{Pt} / \mathrm{TiO}_{2}$ or $\mathrm{MoO}_{3} / \mathrm{TiO}_{2}$ while it increased to $38 \%$ using $564 \mathrm{Mo} / \mathrm{Al}_{2} \mathrm{O}_{3}$. The aliphatic $\mathrm{C}-\mathrm{H}$ contribution on the other hand was most enhanced for $\mathrm{Pt} / \mathrm{TiO}_{2}(48 \%)$, 565 followed by $\mathrm{MoO}_{3} / \mathrm{TiO}_{2}(45 \%)$ and $\mathrm{Mo} / \mathrm{Al}_{2} \mathrm{O}_{3}(42 \%)$. While oxygen containing groups were 566 clearly reduced with all three catalysts, under $50 \mathrm{vol} . \% \mathrm{H}_{2}$ the reduction in oxygen containing 567 groups was least pronounced using $\mathrm{MoO}_{3} / \mathrm{TiO}_{2}$, in agreement with higher TAN and charring 568 propensity of this oil (Table 3). It is worth mentioning that a similar oil quality could be obtained 569 when operating to higher B:C (7.3) at increased $\mathrm{H}_{2}$ concentration of 90 vol.\% (see Table S5). The 570 operating at increased $\mathrm{H}_{2}$ concentration can thus reduce the frequency of catalyst regeneration in 571 a scenario of parallel fixed bed reactors while maintaining a certain oil quality. 
The results from ${ }^{1} \mathrm{H}$ NMR analysis (Table 5) show a slightly higher content of aromatic and

573 conjugated alkene hydrogen $(8.2-6.0 \mathrm{ppm})$ after HDO for all catalysts. Aliphatic H connected to

574 oxygen in sugars and related groups (chemical shifts from 3.0- 6 ppm) show a strong decrease

575 from $\sim 14 \%$ to $\sim 1-3 \%$ after HDO. The oil obtained by $\mathrm{HDO}$ with the $\mathrm{Mo} / \mathrm{Al}_{2} \mathrm{O}_{3}$ catalyst showed

576 the highest contribution of aromatics and conjugated alkene $\mathrm{H}$, followed by $\mathrm{MoO}_{3} / \mathrm{TiO}_{2}$ and

$577 \mathrm{Pt} / \mathrm{TiO}_{2}$, while the aliphatic $\mathrm{H}$ was favored in reverse order, in agreement with the ${ }^{13} \mathrm{C}$ NMR results.

578 The increased aliphatic $\mathrm{H}$ of the $\mathrm{Pt} / \mathrm{TiO}_{2}$ oil agrees with the increased hydrogen incorporation

579 indicated by the higher $\mathrm{EHI}$ and $\mathrm{H} / \mathrm{C}$ ratios of the $\mathrm{Pt} / \mathrm{TiO}_{2}$-derived oils (see Table 3).

580 The lack of ring hydrogenation was checked for monoaromatics and phenol in excess $\mathrm{H}_{2}$

581 (99 vol.\%) by thermodynamic calculations for temperatures $400-475^{\circ} \mathrm{C}$ and hydrogen pressure

582 1-50 bar (see Fig. S24-25). The equilibrium calculations show that higher pressures and/or lower

583 temperatures are needed to hydrogenate the rings.

584 Table 4. Carbon percentage based on the ${ }^{13} \mathrm{C}$ NMR analysis of bio-oils obtained in 50 vol. $\% \mathrm{H}_{2}$ atmosphere (atm. pressure) and B:C $\sim 4$ for the three different $\mathrm{HDO}$ catalysts.

\begin{tabular}{|l|c|c|c|c|}
\hline & No catalyst & $\mathrm{Pt} / \mathrm{TiO}_{2}$ & $\mathrm{MoO}_{3} / \mathrm{Al}_{2} \mathrm{O}_{3}$ & $\mathrm{MoO}_{3} / \mathrm{TiO}_{2}$ \\
\hline Carbonyl (215-166.5 ppm) & $15.4 \%$ & $9.8 \%$ & $8.3 \%$ & $9.3 \%$ \\
\hline Aromatic C-O (166.5-142 ppm) & $12.5 \%$ & $6.7 \%$ & $8.6 \%$ & $10.3 \%$ \\
\hline Aromatic C-C (142-132/125 ppm) & $9.2 \%$ & $4.7 \%$ & $6.4 \%$ & $5.4 \%$ \\
\hline Aromatic C-H (132/125-95.8 ppm) & $16.5 \%$ & 28.0 & $31.8 \%$ & $26.4 \%$ \\
\hline Aliphatic C-O (95.8-60.8 ppm) & $9.9 \%$ & $2.1 \%$ & $2.0 \%$ & $2.4 \%$ \\
\hline Methoxyl (60.8-55.2) & $4.2 \%$ & $0.3 \%$ & $0.4 \%$ & $1.3 \%$ \\
\hline $\begin{array}{l}\text { Aliphatic C-H (55.2-0 ppm, with } \\
\text { exclusion of solvent) }\end{array}$ & $32.4 \%$ & $48.4 \%$ & $42.5 \%$ & $44.8 \%$ \\
\hline
\end{tabular}

${ }^{\mathrm{a}}$ For catalytically treated pyrolysis bio-oils, the border between aromatic $\mathrm{C}-\mathrm{C}$ and aromatic $\mathrm{C}-\mathrm{H}$ was

587 moved downfield from $125 \mathrm{ppm}$ to $132 \mathrm{ppm}$ following the recommendation of Happs et al. [68]. 
Table 5. Hydrogen percentage based on the ${ }^{1} \mathrm{H}$ NMR analysis of bio-oils, obtained in 50 vol.\% $\mathrm{H}_{2}$ atmosphere (atm. pressure) and B:C $\sim 4$ for the three different $\mathrm{HDO}$ catalysts.

\begin{tabular}{|l|c|c|c|c|}
\hline assignment & No catalyst & $\mathrm{Pt} / \mathrm{TiO}_{2}$ & $\mathrm{MoO}_{3} / \mathrm{Al}_{2} \mathrm{O}_{3}$ & $\mathrm{MoO}_{3} / \mathrm{TiO}_{2}$ \\
\hline$-\mathrm{COOH}(12.5-11.0 \mathrm{ppm})$ & $0.1 \%$ & $0.1 \%$ & $0.1 \%$ & $0.0 \%$ \\
\hline$-\mathrm{CHO}, \mathrm{ArOH}(11.0-8.2 \mathrm{ppm})$ & $0.8 \%$ & $0.5 \%$ & $1.1 \%$ & $0.7 \%$ \\
\hline $\begin{array}{l}\text { aromatics and } \\
\text { conjugated alkene } \mathrm{H}(8.2-6.0 \mathrm{ppm})\end{array}$ & $18.5 \%$ & $20.6 \%$ & $23.2 \%$ & $21.5 \%$ \\
\hline $\begin{array}{l}\text { aliphatic } \mathrm{OH},-\mathrm{CH}=\mathrm{CH}-, \mathrm{Ar}-\mathrm{CH}_{2}-\mathrm{O}-\mathrm{R} \\
(6.0-4.2 \mathrm{ppm})\end{array}$ & $5.6 \%$ & $1.4 \%$ & $1.7 \%$ & $2.7 \%$ \\
\hline $\mathrm{R}-\mathrm{CH}_{2}-\mathrm{O}-\mathrm{R}, \mathrm{CH}_{3}-\mathrm{O}-\mathrm{R}(4.2-3.0 \mathrm{ppm})$ & $13.9 \%$ & $0.8 \%$ & $1.3 \%$ & $3.6 \%$ \\
\hline$-\mathrm{CH}_{2} \mathrm{CH}=\mathrm{O}$, aliphatic $\mathrm{H}(3.0-2.0 \mathrm{ppm})$ & $24.6 \%$ & $44.2 \%$ & $42.8 \%$ & $40.7 \%$ \\
\hline aliphatic proton $(2.0-0 \mathrm{ppm})$ & $36.5 \%$ & $32.5 \%$ & $29.7 \%$ & $30.8 \%$ \\
\hline
\end{tabular}

Compared to 1D NMR spectra required for quantification, 2D NMR spectra lower the likelihood

592 of overlapping signals because the signals are spread out into two dimensions. The heteronuclear

593 single-quantum correlation spectroscopy (HSQC) correlates chemical shifts of carbons and

594 protons in a phase sensitive way. The 2D HSQC spectra of oils analyzed by 1D NMR are provided

595 in Fig. S19-S23. Oils obtained from the catalytic vapor treatment with HDO catalysts showed a

596 clear decrease in the contribution of - $\mathrm{CH}-\mathrm{O}-$ and $-\mathrm{O}-\mathrm{CH}-\mathrm{O}-$ groups, which are mainly present in

597 sugars. Aldehydes were converted almost completely using $\mathrm{Pt} / \mathrm{TiO}_{2}$ while a higher concentration

598 of aldehydes remained for the oil obtained from $\mathrm{HDO}$ with $\mathrm{Mo} / \mathrm{Al}_{2} \mathrm{O}_{3}$.

\subsection{Coke on catalyst}

600 The regeneration of coke species on the three HDO catalysts occurred at lower combustion

601 temperatures compared to regeneration of coked $\mathrm{Al}_{2} \mathrm{O}_{3}$ or HZSM-5 (see Fig. 5a). The TiO $2^{-}$

602 supported catalysts showed the lowest combustion temperature. The observation might be a 603 combined effect of a combustion-catalytic effect by $\mathrm{Pt}$ and $\mathrm{MoO}_{3}$, as well as differences in the

604 coke properties. While not further investigated in this work, the coke species from HDO may 605 contain higher $\mathrm{H} / \mathrm{C}$ ratios compared to the more graphitic coke inside zeolitic micropores. For HDO of a lignin model compound (m-cresol), Shetty et al. [43] reported that an $\mathrm{Al}_{2} \mathrm{O}_{3}$-supported

$607 \mathrm{MoO}_{3}$ showed a higher tendency to form refractory graphitic coke compared to $\mathrm{TiO}_{2}$ and $\mathrm{ZrO}_{2-}$ 608 supported $\mathrm{MoO}_{3}$ catalysts, thereby requiring higher temperatures for oxidative regeneration, which 609 agrees with our observations. The onset of coke-combustion for the coke deposited on $\mathrm{TiO}_{2}$ from 
610 upgrading under $\mathrm{N}_{2}$ atmosphere occurred at higher temperatures $\left(\sim 275^{\circ} \mathrm{C}\right)$ compared to the Pt and

$611 \mathrm{MoO}_{3}$-promoted $\mathrm{TiO}_{2}$ catalysts (not shown). Fig. 5b shows a comparison of the deposited mass of

612 coke (carbon) per mass of coke-free catalyst towards higher B:C ratios for the different HDO

613 catalysts and acidic catalysts such as $\gamma-\mathrm{Al}_{2} \mathrm{O}_{3}$ and $\mathrm{HZSM}-5$ zeolite [14]. The coking propensity of

$614 \gamma-\mathrm{Al}_{2} \mathrm{O}_{3}$ is rather high, while the microporosity of HZSM-5 limits the coke formation [14]. The

615 coking propensity of bare $\mathrm{TiO}_{2}$ under nitrogen atmosphere was in the same range as HZSM-5. The

$616 \mathrm{Pt} / \mathrm{TiO}_{2}$ catalyst formed less coke per mass of catalyst compared to HZSM-5 zeolite and the bare

$617 \mathrm{TiO}_{2}$ support, which could indicate that hydrogenation of coke precursors and coke scavenging

618 occurred near the active Pt sites. Coke scavenging was observed in micropyrolyzer tests where $\mathrm{H}_{2}$

619 continued to flow over the catalyst in between pyrolysis vapor pulses [47]. Remarkably, the HDO

620 using $\mathrm{Pt} / \mathrm{TiO}_{2}$ resulted in only a slight additional buildup of coke compared to the coke that had

621 initially deposited at $\mathrm{B}: \mathrm{C} \sim 1.2$, even though the catalyst was still active and improved the fuel

622 properties of the condensed bio-oil up to high $\mathrm{B}: \mathrm{C}$ of $\sim 8$ (see Table 3 ). This is attractive as it limits

623 carbon losses to coke and eventually $\mathrm{CO}_{2}$ during the catalyst regeneration. The coking propensity

624 of $\mathrm{MoO}_{3} / \mathrm{TiO}_{2}$ was slightly higher compared to $\mathrm{Pt} / \mathrm{TiO}_{2}$, yet below the coking propensity of

625 HZSM-5. We further note that an increase in $\mathrm{H}_{2}$ concentration from 50 to 90 vol.\% led to a slight

626 decrease in coke deposition for the $\mathrm{MoO}_{3} / \mathrm{TiO}_{2}$ and $\mathrm{Pt} / \mathrm{TiO}_{2}$ catalysts (Fig. 5). Compared per

627 surface area of catalyst, 0.96 and $1.29 \mathrm{mg} \mathrm{C} / \mathrm{m}^{2}$ deposited using $\mathrm{Pt} / \mathrm{TiO}_{2}$ and $\mathrm{MoO}_{3} / \mathrm{TiO}_{2}$ catalyst

628 at 50 vol. $\% \mathrm{H}_{2}$, which decreased to 0.86 and $1.07 \mathrm{mg} / \mathrm{m}^{2}$ at increased $\mathrm{H}_{2}$ concentration of 90 vol. $\%$.

629 Amongst the three tested HDO catalysts, the coking propensity of the industrial $\mathrm{MoO}_{3} / \mathrm{Al}_{2} \mathrm{O}_{3}$ was

630 the highest, which we tentatively attribute to a higher surface area and acidity of the $\mathrm{Al}_{2} \mathrm{O}_{3}$ support

631 compared to $\mathrm{TiO}_{2}$. 

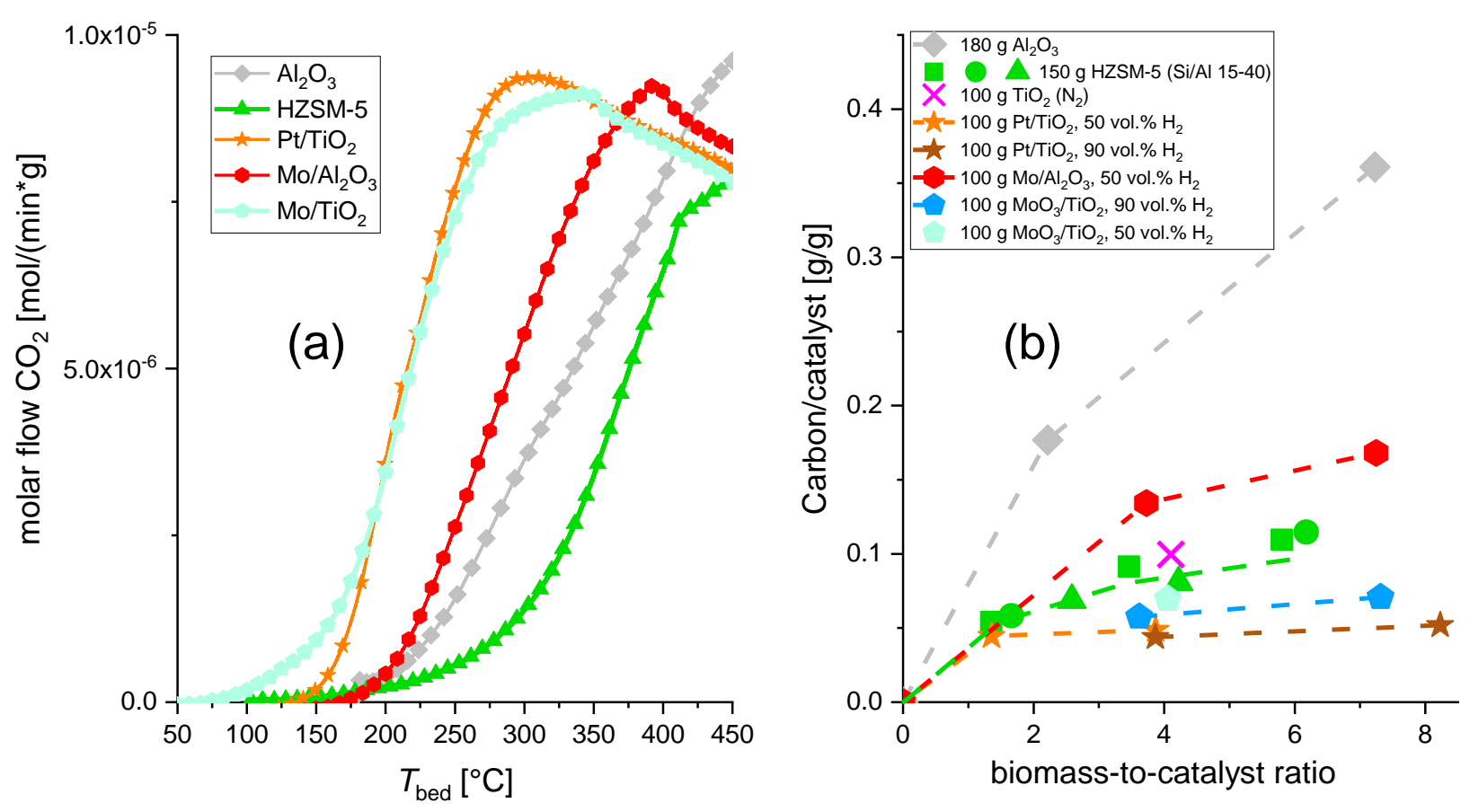

633 Fig. 5. (a) $\mathrm{CO}_{2}$ evolution during coke combustion (B:C 4) of the full catalyst bed in $\sim 2$ vol. $\% \mathrm{O}_{2} / \mathrm{N}_{2}$ during 634 heating at $1{ }^{\circ} \mathrm{C} / \mathrm{min}$. HDO tests were conducted in $50 \mathrm{vol} . \% \mathrm{H}_{2}$. (b) Deposited mass of carbon in coke per 635 coke-free catalyst for different catalysts and towards higher $\mathrm{B}: \mathrm{C}$ ratios. Data points for $\gamma-\mathrm{Al}_{2} \mathrm{O}_{3}$ and $\mathrm{HZSM}-$ 6365 have been reported earlier [14,62].

$637 \quad 3.5$ Catalyst stability

638 In order to investigate potential sintering of small $\mathrm{Pt}$ particles, the $\mathrm{Pt} / \mathrm{TiO}_{2}$ catalyst was re639 analyzed by TEM after four cycles of reaction and regeneration. Representative TEM images and 640 the particle size distributions obtained from $~ 200$ particles of $\sim 10$ different sample locations are 641 shown in Fig. S26. The Pt particles remain well dispersed on the support. While the peak of the 642 particle size distribution remains centered at $\sim 1.5 \mathrm{~nm}$ similar to the pre-reaction characterization 643 (Fig. S7c), the post-reaction particle size distribution extended to larger particles up to $\sim 5 \mathrm{~nm}$ (Fig. 644 S26f). The post-reaction characterization of the regenerated $\mathrm{TiO}_{2}$-supported catalysts showed only 645 minimal changes in surface area, as the surface area slightly increased from 51 to $54 \mathrm{~m}^{2} / \mathrm{g}$ for $646 \mathrm{Pt} / \mathrm{TiO}_{2}$ and slightly decreased from 54 to $49 \mathrm{~m}^{2} / \mathrm{g}$ for $\mathrm{MoO}_{3} / \mathrm{TiO}_{2}$. Griffin et al. [41] reported 647 minimal changes to the $\mathrm{TiO}_{2}$ support after 13 reaction/regeneration cycles, albeit a more 
648 pronounced increase in Pt particle size was observed in their work-yet without any apparent 649 impact on performance.

650 A sample of spent $\mathrm{MoO}_{3} / \mathrm{TiO}_{2}$ catalyst that was obtained after three reaction-regeneration cycles 651 using straw as feedstock and after three additional cycles using lignin as feedstock (not reported 652 in this work) was subjected to XRD analysis. Noticeably, the $\mathrm{MoO}_{3}$-related peaks had decreased 653 in intensity for the spent catalyst (see Fig. S3). From molybdenum-containing catalysts used for 654 the oxidation of methanol in the temperature range of $300-400{ }^{\circ} \mathrm{C}$, it is known that Mo can form 655 volatile species with methanol and also with water [76-81]. Despite the presence of small 656 oxygenates including $\mathrm{MeOH}$ and $\sim 15$ vol.\% steam during reaction conditions, the analysis of the 657 Mo content of the spent catalyst amounted to $6.7 \mathrm{wt} \%$. As such, no loss of Mo could be concluded 658 within this work, indicating a strong interaction with the support. The smaller and broader $\mathrm{MoO}_{3}-$ 659 related peaks observed for the spent sample may indicate that $\mathrm{MoO}_{3}$ on the fresh $\mathrm{MoO}_{3} / \mathrm{TiO}_{2}$ 660 dispersed into smaller and better-distributed domains under the reaction conditions.

6613.6 Energy recovery

662 It is of interest to benchmark the performance of the HDO catalysts against each other and 663 against other acidic catalysts such as $\mathrm{HZSM}-5$ zeolite, $\mathrm{Al}_{2} \mathrm{O}_{3}$, and $\mathrm{HZSM}-5 / \mathrm{Al}_{2} \mathrm{O}_{3}$ extrudates 664 [14,62]. Fig. 6 shows the degree of deoxygenation (DOD) obtained in the collected bio-oil and 665 their energy recovery with respect to bio-oil obtained without catalyst in $\mathrm{N}_{2}$ atmosphere. When 666 using acidic catalysts for vapor upgrading under $\mathrm{N}_{2}$ atmosphere, the deoxygenation rapidly 667 decreased towards higher B:C ratio while the energy recovery of the oil increased (Fig. 6). 668 Interestingly, a $\sim 5 \%$ higher energy recovery of the condensed oil phase was obtained when 669 switching to $50 \mathrm{vol} . \% \mathrm{H}_{2}$ without using a catalyst. This is attributed to a slight hydrodeoxygenation 670 achieved by the metal surfaces inside the pyrolysis system or metals in the char/ash with catalytic 671 activity, which is consistent with a slight increase in reaction water due to HDO and a reduction 
672 in the oil's oxygen content by $20 \%$. While the overall yield of liquid-range organics was

673 comparable (Fig. 1), this led to a more favorable phase separation between organic and aqueous

674 phase with a decreased yield of (polar) organic compounds in the aqueous phase. The application

675 of atmospheric HDO achieved higher energy recoveries for a given level of deoxygenation

676 compared to the acidic catalysts (Fig. 6). While obtaining the same energy recovery as the non-

677 catalytic oil $\left(\mathrm{N}_{2}\right)$, almost $60 \%$ deoxygenation was achieved with $\mathrm{Pt} / \mathrm{TiO}_{2}$ at $\mathrm{B}: \mathrm{C} \sim 4$ and 50 vol.\%

$678 \mathrm{H}_{2}$. Note that at lower B:C (1.4) a lower oxygen content can be obtained albeit at lower energy

679 recovery due to increased losses to gas and coke (Fig. 1). Amongst the three HDO catalysts tested

680 at 50 vol. $\% \mathrm{H}_{2}$, the industrial Mo based catalyst achieved the lowest energy recoveries compared

681 at similar vapor deoxygenation, which correlated with higher gas and coke yields. At 50 vol. $\% \mathrm{H}_{2}$,

$682 \mathrm{MoO}_{3} / \mathrm{TiO}_{2}$ performed identical to $\mathrm{Pt} / \mathrm{TiO}_{2}$ in terms of deoxygenation and energy recovery of

683 condensed bio-oil: $\sim 60 \%$ deoxygenation of oil was obtained at a similar energy recovery (101\%)

684 of bio-oil fraction compared to the non-catalytic reference case without hydrogen addition. The

685 lower hydrogenation activity of Mo compared to Pt was seemingly compensated by the

686 significantly higher loading of $\mathrm{Mo}$ on $\mathrm{TiO}_{2}$ (11 times higher than $\mathrm{Pt}$ ) leading to roughly similar

687 activity of the two catalysts. An increase in $\mathrm{H}_{2}$ partial pressure from 50 to $90 \mathrm{vol} . \% \mathrm{H}_{2}$ further

688 increased the deoxygenation and energy recovery of the bio-oils. At $90 \mathrm{vol} . \% \mathrm{H}_{2}$, energy recoveries

689 of bio-oil with respect to the fed biomass of 42 and $39 \%$ were obtained with bio-oil oxygen

690 contents of 10 and 8 wt.\% (d.b.) using the $\mathrm{Pt} / \mathrm{TiO}_{2}$ and $\mathrm{MoO}_{3} / \mathrm{TiO}_{2}$ catalyst, respectively. With

691 operation to $\mathrm{B}: \mathrm{C}$ of $7-8$, the extent of deoxygenation decreased for both $\mathrm{Pt} / \mathrm{TiO}_{2}$ and $\mathrm{MoO}_{3} / \mathrm{TiO}_{2}$

692 catalyst while the oil yield increased (see Fig. 1). For $\mathrm{Pt} / \mathrm{TiO}_{2}$ this led to a slight increase in energy

693 recovery, while for $\mathrm{MoO}_{3} / \mathrm{TiO}_{2}$ the energy recovery decreased due to the lower heating value of 
694 the oil (36.5 vs. $37.7 \mathrm{MJ} / \mathrm{kg}$ ), thereby approaching the results obtained at lower $\mathrm{H}_{2}$ concentration 695 and $\mathrm{B}: \mathrm{C} \sim 4$.

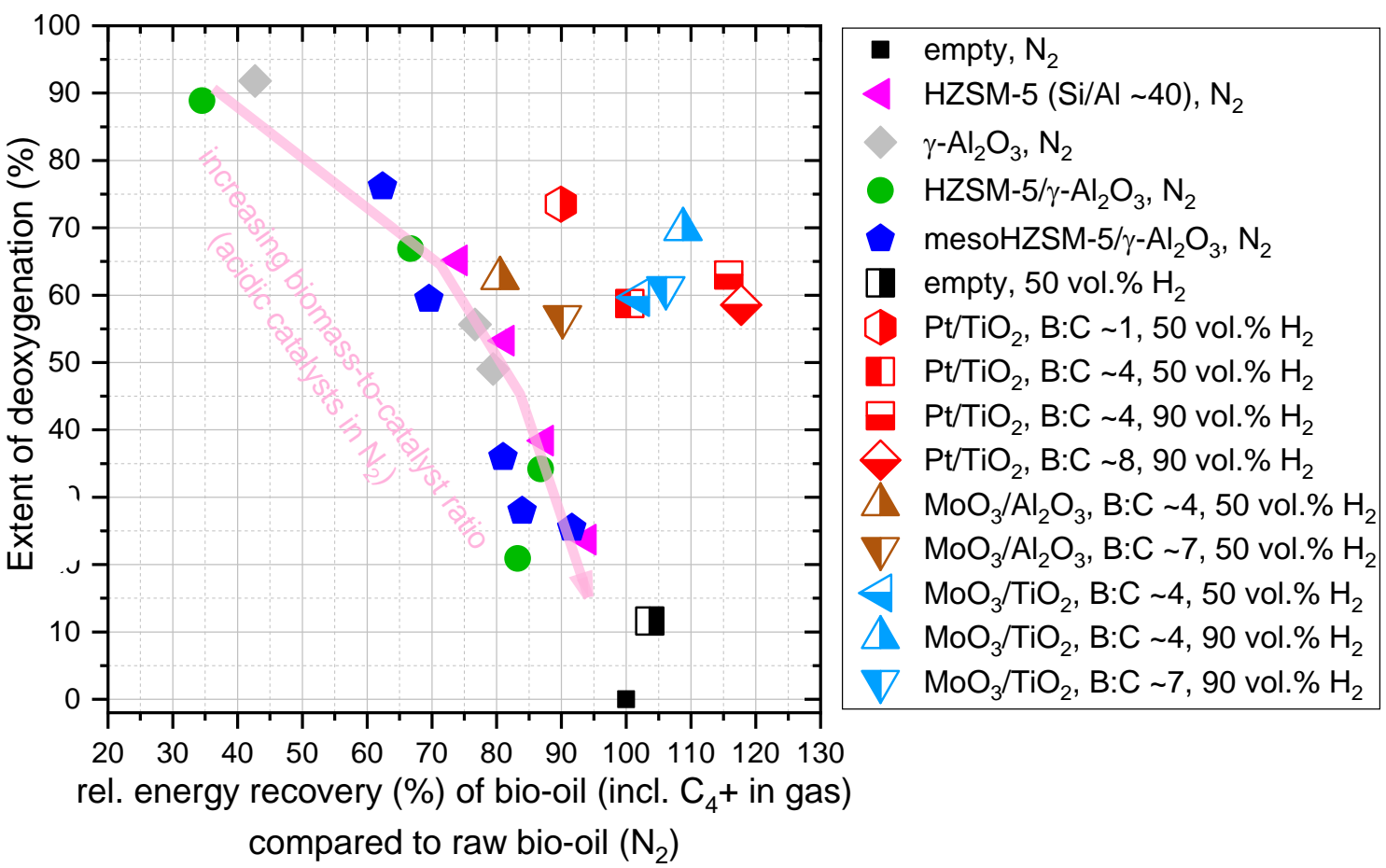

697 Fig. 6. Deoxygenation and energy recovery of bio-oil obtained with HDO catalysts at $400-450{ }^{\circ} \mathrm{C}$ (half698 filled symbols) and acidic catalysts at $500{ }^{\circ} \mathrm{C}$ (filled symbols) relative to a non-catalytic bio-oil obtained under inert conditions $\left(\mathrm{N}_{2}\right)$ with 26 wt. $\% \mathrm{O}$ (d.b.) and $36 \%$ energy recovery.

\subsection{Catalyst cost estimation}

701

In order to obtain a rough cost comparison of the two in-house prepared $\mathrm{TiO}_{2}$-supported catalysts, the estimation tool CatCost [82], provided by the DOE/NREL/ALLIANCE, was used.

703 The material cost of $10 \mathrm{wt} . \% \mathrm{MoO}_{3} / \mathrm{TiO}_{2}$ catalyst was estimated to be $\sim 4300$ \$/ton of catalyst, with

704 zero value of the spent catalyst. The material cost of $0.5 \mathrm{wt} \% \mathrm{Pt} / \mathrm{TiO}_{2}$ catalyst was significantly 705 higher ( 118000 \$/ton of catalyst), but the spent catalyst value was estimated to be $\sim 92700 \$ /$ ton 706 of catalyst. The Pt catalyst therefore has much higher investment costs, and even when taking the 707 value of the spent catalyst into account, the $\mathrm{Pt} / \mathrm{TiO}_{2}$ catalyst would be almost 6 times more 708 expensive compared to the $10 \mathrm{wt} . \% \mathrm{MoO}_{3} / \mathrm{TiO}_{2}$ catalyst. This speaks for the latter catalyst, since 709 it achieved similar performance to $\mathrm{Pt} / \mathrm{TiO}_{2}$, especially at higher $\mathrm{H}_{2}$ partial pressure; however, 
710 further optimization of the Pt loading of the $\mathrm{Pt} / \mathrm{TiO}_{2}$, and possibly $\mathrm{Pt}$ particle size [83,84], should

711 be carried out before a firm conclusion can be drawn.

\section{CONCLUSION}

713 Atmospheric hydro-deoxygenation (HDO) of wheat straw fast pyrolysis vapors was investigated

714 in a continuous flow setup using $100 \mathrm{~g}$ of $0.5 \mathrm{wt} . \% \mathrm{Pt} / \mathrm{TiO}_{2}, 10 \mathrm{wt} \% \mathrm{MoO}_{3} / \mathrm{TiO}_{2}$, or an industrial

$715 \mathrm{MoO}_{3} / \mathrm{Al}_{2} \mathrm{O}_{3}$ catalyst. The HDO provided higher energy recoveries of bio-oils compared to acidic

716 catalysts such as $\gamma-\mathrm{Al}_{2} \mathrm{O}_{3}$ or $\mathrm{HZSM}-5$ zeolite, which is attributed to carbon preserving HDO

717 reactions, $\mathrm{H}_{2}$ incorporation, and a reduction in polarity of the compounds, thereby reducing losses

718 to the aqueous phase. At $50 \mathrm{vol} . \% \mathrm{H}_{2}$, the performance of the industrial Mo based catalyst was the

719 poorest, with the highest gas and coke yields. $10 \mathrm{wt} . \% \mathrm{MoO}_{3} / \mathrm{TiO}_{2}$ performed identical to $0.5 \mathrm{wt} . \%$

$720 \mathrm{Pt} / \mathrm{TiO}_{2}$ at 50 vol.\% $\mathrm{H}_{2}$ and obtained oil with $\sim 11 \mathrm{wt} \% \mathrm{O}, 31 \mathrm{C} \%$ and $36 \%$ energy recovery. The

721 carbon and energy recovery could be further improved by increasing the hydrogen concentration

722 in the gas to 90 vol.\%, yielding oils with 8-10 wt.\% O (dry basis) and 39-42 \% energy recovery.

723 This further decreased the acidity (TAN) of the bio-oil to as low as $2 \mathrm{mg} \mathrm{KOH} / \mathrm{g}$ when using

$724 \mathrm{Pt} / \mathrm{TiO}_{2}$ (non-catalytic $=66 \mathrm{mg} \mathrm{KOH} / \mathrm{g}$ ). Oils obtained from $\mathrm{HDO}$ using $\mathrm{Pt} / \mathrm{TiO}_{2}$ catalyst showed

725 a higher aliphatic content compared to the Mo based catalysts, which reduced the charring

726 tendency during heating of the bio-oil. Methoxyphenols that are present in non-treated bio-oil were

727 not detected in the upgraded bio-oils and thus were likely converted to aromatic hydrocarbons or

728 partially deoxygenated into phenols.

729 For the deoxygenation of biomass fast pyrolysis vapors, it is critical to balance the

730 deoxygenation severity with the carbon losses during deoxygenation. The application of

731 atmospheric pressure catalytic HDO reduced the losses of carbon to the aqueous phase and coke

732 and increased the carbon recovery of bio-oil with improved fuel properties, which may be further 
733 processed in conventional refineries or directly applied as a renewable fuel, e.g. for ship engines.

734 The presented data may facilitate future techno-economic assessment for the production of

735 transportation fuels from agricultural residues.

736 ASSOCIATED CONTENT

737 Supporting Information: Scheme of bench-scale fast pyrolysis unit; Temperature of catalyst

738 during reaction; Isotherms and pore size distribution from $\mathrm{N}_{2}$ physisorption; $\mathrm{NH}_{3}-\mathrm{TPD}$ acidity

739 characterization; Pyridine FT-IR characterization; pre and post-reaction TEM images and

740 particle size distribution; concentration of light hydrocarbons during reaction over $\mathrm{Pt} / \mathrm{TiO}_{2}$;

741 thermo-gravimetric analysis of bio-oils; GC $\times \mathrm{GC}$ plots; ${ }^{13} \mathrm{C}$ NMR and 2D NMR spectra of bio-

742 oils;

\section{AUTHOR INFORMATION}

\section{Corresponding Author:}

$745 \quad *$ aj@kt.dtu.dk (Anker Degn Jensen)

\section{Author Contributions}

747 The manuscript was written through contributions of all authors. All authors have given approval 748 to the final version of the manuscript.

749 CONFLICTS OF INTEREST

750 There are no conflicts to declare.

751 ACKNOWLEDGMENT

752 Funding by the Danish Energy Technology Development and Demonstration Program (EUDP

753 project number 12454) is gratefully acknowledged. Alireza Saraeian and Brent H. Shanks would 
754 like to acknowledge funding from the Iowa Energy Center, Iowa Economic Development

755 Authority and its utility partners under the grant number 17-IEC-002.

\section{ABBREVIATIONS}

757 daf, dry and ash-free; d.b., dry basis; DOD, degree of deoxygenation; FID, flame ionization

758 detection; GC, gas chromatography; HDO, hydrodeoxygenation, MS, mass spectrometry; TEM,

759 transmission electron microscopy; TGA, thermogravimetric analysis; TPD, temperature-

760 programmed desorption; 


\section{REFERENCES}

[1] A.J. Toft, A comparison of integrated biomass to electricity systems, The University of Aston in Birmingham, 1996.

[2] D. Mourant, C. Lievens, R. Gunawan, Y. Wang, X. Hu, L. Wu, S.S.A. Syed-Hassan, C.-Z. Li, Effects of temperature on the yields and properties of bio-oil from the fast pyrolysis of mallee bark, Fuel. 108 (2013) 400-408. doi:10.1016/J.FUEL.2012.12.018.

[3] N. Ibrahim, Bio-oil from Flash Pyrolysis of Agricultural Residues, DTU Chemical Engineering, 2012. https://orbit.dtu.dk/en/publications/bio-oil-from-flash-pyrolysis-of-agricultural-residues (accessed November $28,2019)$.

[4] D.S. Scott, J. Piskorz, The Continuous Flash Pyrolysis of Biomass, Can. J. Chem. Eng. 62 (1984) 404.

[5] N. Bech, M.B. Larsen, P.A. Jensen, K. Dam-Johansen, Modelling solid-convective flash pyrolysis of straw and wood in the Pyrolysis Centrifuge Reactor, Biomass and Bioenergy. 33 (2009) 999-1011. doi:10.1016/j.biombioe.2009.03.009.

[6] H. Hernando, S. Jiménez-Sánchez, J. Fermoso, P. Pizarro, J.M. Coronado, D.P. Serrano, Assessing biomass catalytic pyrolysis in terms of deoxygenation pathways and energy yields for the efficient production of advanced biofuels, Catal. Sci. Technol. 6 (2016) 2829-2843. doi:10.1039/c6cy00522e.

[7] H.L. Chum, R.P. Overend, Biomass and renewable fuels, Fuel Process. Technol. 71 (2001) 187-195. doi:10.1016/S0378-3820(01)00146-1.

[8] M. Shemfe, S. Gu, B. Fidalgo, Techno-economic analysis of biofuel production via bio-oil zeolite upgrading: An evaluation of two catalyst regeneration systems, Biomass and Bioenergy. 98 (2017) 182-193. doi:10.1016/j.biombioe.2017.01.020.

[9] L. Faba, E. Díaz, S. Ordóñez, Recent developments on the catalytic technologies for the transformation of biomass into biofuels: A patent survey, Renew. Sustain. Energy Rev. 51 (2015) 273-287. doi:10.1016/j.rser.2015.06.020.

[10] M.S. Talmadge, R.M. Baldwin, M.J. Biddy, R.L. McCormick, G.T. Beckham, G.A. Ferguson, S. Czernik, K. Magrini, T.D. Foust, P.D. Metelski, C. Hetrick, M.R. Nimlos, A perspective on oxygenated species in the refinery integration of pyrolysis oil, Green Chem. 16 (2014) 407-453. doi:10.1039/C3GC41951G.

[11] A. V. Bridgwater, Review of fast pyrolysis of biomass and product upgrading, Biomass and Bioenergy. 38 (2012) 68-94. doi:10.1016/j.biombioe.2011.01.048.

[12] R. French, S. Czernik, Catalytic pyrolysis of biomass for biofuels production, Fuel Process. Technol. 91 (2010) 25-32. doi:10.1016/j.fuproc.2009.08.011.

[13] A. Eschenbacher, P.A. Jensen, U.B. Henriksen, J. Ahrenfeldt, C. Li, J.Ø. Duus, U.V. Mentzel, A.D. Jensen, Impact of ZSM-5 deactivation on bio-oil quality during upgrading of straw derived pyrolysis vapors, Energy \& Fuels. 33 (2019) 397-412. doi:10.1021/acs.energyfuels.8b03691.

[14] A. Eschenbacher, P.A. Jensen, U.B. Henriksen, J. Ahrenfeldt, C. Li, J.Ø. Duus, U.V. Mentzel, A.D. Jensen, Deoxygenation of wheat straw fast pyrolysis vapors using HZSM-5, Al2O3, HZSM-5/Al2O3 extrudates, and desilicated HZSM-5/A12O3 extrudates, Energy \& Fuels. (2019) acs.energyfuels.9b00906. doi:10.1021/acs.energyfuels.9b00906.

[15] A. Oasmaa, D.C. Elliott, J. Korhonen, Acidity of biomass fast pyrolysis bio-oils, Energy and Fuels. 24 (2010) 6548-6554. doi:10.1021/ef100935r.

[16] S. Bezergianni, A. Dimitriadis, O. Kikhtyanin, D. Kubička, Refinery co-processing of renewable feeds, Prog. Energy Combust. Sci. 68 (2018) 29-64. doi:10.1016/j.pecs.2018.04.002.

[17] C. Wang, M. Li, Y. Fang, Coprocessing of Catalytic-Pyrolysis-Derived Bio-Oil with VGO in a Pilot-Scale FCC Riser, Ind. Eng. Chem. Res. 55 (2016) 3525-3534. doi:10.1021/acs.iecr.5b03008.

[18] A. Oasmaa, S. Czernik, Fuel oil quality of biomass pyrolysis oil - State of the art for the end users, Energy \& Fuels. 13 (1999) 914-921. doi:10.1021/ef980272b.

[19] S. Czernik, A. V. Bridgwater, Overview of applications of biomass fast pyrolysis oil, Energy \& Fuels. 18 (2004) 590-598. doi:10.1021/ef034067u.

[20] A. Saraeian, M.W. Nolte, B.H. Shanks, Deoxygenation of biomass pyrolysis vapors: Improving clarity on the fate of carbon, Renew. Sustain. Energy Rev. 104 (2019) 262-280. doi:10.1016/j.rser.2019.01.037.

[21] R.H. Venderbosch, A critical view on catalytic pyrolysis of biomass, ChemSusChem. 8 (2015) 1306-1316. doi:10.1002/cssc.201500115.

[22] J. Jae, G.A. Tompsett, A.J. Foster, K.D. Hammond, S.M. Auerbach, R.F. Lobo, G.W. Huber, Investigation into the shape selectivity of zeolite catalysts for biomass conversion, J. Catal. 279 (2011) 257-268. 
doi:10.1016/j.jcat.2011.01.019.

[23] T.R. Carlson, G.A. Tompsett, W.C. Conner, G.W. Huber, Aromatic production from catalytic fast pyrolysis of biomass-derived feedstocks, Top. Catal. 52 (2009) 241-252. doi:10.1007/s11244-008-9160-6.

[24] P.A. Horne, P.T. Williams, The effect of zeolite ZSM-5 catalyst deactivation during the upgrading of biomassderived pyrolysis vapours, J. Anal. Appl. Pyrolysis. 34 (1995) 65-85. doi:10.1016/0165-2370(94)00875-2.

[25] S. Wan, T. Pham, S. Zhang, L. Lobban, D. Resasco, R. Mallinson, Direct catalytic upgrading of biomass pyrolysis vapors by a dual function $\mathrm{Ru} / \mathrm{TiO}_{2}$ catalyst, AIChE J. 59 (2013) 2275-2285. doi:10.1002/aic.14038.

[26] R. Kumar, N. Enjamuri, S. Shah, A.S. Al-Fatesh, J.J. Bravo-Suárez, B. Chowdhury, Ketonization of oxygenated hydrocarbons on metal oxide based catalysts, Catal. Today. (2017). doi:10.1016/j.cattod.2017.09.044.

[27] T.N. Pham, T. Sooknoi, S.P. Crossley, D. Resasco, Ketonization of carboxylic acids: Mechanism, catalysts, and implications for biomass concersion, Am. Chem. Soc. Catal. 3 (2013) 2456-2473.

[28] O. Nagashima, S. Sato, R. Takahashi, T. Sodesawa, Ketonization of carboxylic acids over CeO 2-based composite oxides, J. Mol. Catal. A Chem. 227 (2005) 231-239. doi:10.1016/j.molcata.2004.10.042.

[29] O.D. Mante, J. a. Rodriguez, S.D. Senanayake, S.P. Babu, Catalytic conversion of biomass pyrolysis vapors into hydrocarbon fuel precursors, Green Chem. 17 (2015) 2362-2368. doi:10.1039/C4GC02238F.

[30] Q. Lu, Y. Zhang, Z. Tang, W.Z. Li, X.F. Zhu, Catalytic upgrading of biomass fast pyrolysis vapors with titania and zirconia/titania based catalysts, Fuel. 89 (2010) 2096-2103. doi:10.1016/j.fuel.2010.02.030.

[31] Q. Lu, Z.B. Zhang, X.Q. Wang, C.Q. Dong, Y.Q. Liu, Catalytic upgrading of biomass fast pyrolysis vapors using ordered mesoporous $\mathrm{ZrO} 2, \mathrm{TiO} 2$ and $\mathrm{SiO} 2$, Energy Procedia. 61 (2014) 1937-1941. doi:10.1016/j.egypro.2014.12.247.

[32] P. Kaewpengkrow, D. Atong, V. Sricharoenchaikul, Catalytic upgrading of pyrolysis vapors from Jatropha wastes using alumina, zirconia and titania based catalysts, Bioresour. Technol. 163 (2014) 262-269. doi:10.1016/j.biortech.2014.04.035.

[33] K.S. Kim, M.A. Barteau, Structure and composition requirements for deoxygenation, dehydration, and ketonization reactions of carboxylic acids on TiO2(001) single-crystal surfaces, J. Catal. 125 (1990) 353-375. doi:10.1016/0021-9517(90)90309-8.

[34] R. Pestman, R.M. Koster, A. van Duijne, J.A.Z. Pieterse, V. Ponec, Reactions of Carboxylic Acids on Oxides, J. Catal. 168 (1997) 265-272. doi:10.1006/jcat.1997.1624.

[35] O.D. Mante, J.A. Rodriguez, S.P. Babu, Selective defunctionalization by $\mathrm{TiO} 2$ of monomeric phenolics from lignin pyrolysis into simple phenols, Bioresour. Technol. 148 (2013) 508-516. doi:10.1016/j.biortech.2013.09.003.

[36] M.B. Griffin, G.A. Ferguson, D.A. Ruddy, M.J. Biddy, G.T. Beckham, J.A. Schaidle, Role of the Support and Reaction Conditions on the Vapor-Phase Deoxygenation of m-Cresol over Pt/C and Pt/TiO2 Catalysts, ACS Catal. 6 (2016) 2715-2727. doi:10.1021/acscatal.5b02868.

[37] S.M. Schimming, O.D. LaMont, M. König, A.K. Rogers, A.D. D’Amico, M.M. Yung, C. Sievers, Hydrodeoxygenation of Guaiacol over Ceria-Zirconia Catalysts, ChemSusChem. 8 (2015) 2073-2083. doi:10.1002/cssc.201500317.

[38] P.M. de Souza, R.C. Rabelo-Neto, L.E.P. Borges, G. Jacobs, B.H. Davis, U.M. Graham, D.E. Resasco, F.B. Noronha, Effect of Zirconia Morphology on Hydrodeoxygenation of Phenol over Pd/ZrO ${ }_{2}$, ACS Catal. 5 (2015) 7385-7398. doi:10.1021/acscatal.5b01501.

[39] S. Boonyasuwat, T. Omotoso, D.E. Resasco, S.P. Crossley, Conversion of guaiacol over supported Ru catalysts, Catal. Letters. 143 (2013) 783-791. doi:10.1007/s10562-013-1033-3.

[40] M.B. Griffin, G.A. Ferguson, D.A. Ruddy, M.J. Biddy, G.T. Beckham, J.A. Schaidle, Role of the Support and Reaction Conditions on the Vapor-Phase Deoxygenation of $m$-Cresol over Pt/C and Pt/TiO 2 Catalysts, ACS Catal. 6 (2016) 2715-2727. doi:10.1021/acscatal.5b02868.

[41] M.B. Griffin, K. Iisa, H. Wang, A. Dutta, K.A. Orton, R.J. French, D.M. Santosa, A.N. Wilson, E.D. Christensen, C. Nash, F.G. Baddour, K. Van Allsburg, D.A. Ruddy, C. Mukarakate, J.A. Schaidle, Driving towards cost-competitive biofuels through catalytic fast pyrolysis by rethinking catalyst selection and reactor configuration, Energy Environ. Sci. Accepted w (2018). doi:10.1039/C8EE01872C.

[42] T. Prasomsri, T. Nimmanwudipong, Y. Román-Leshkov, Effective hydrodeoxygenation of biomass-derived oxygenates into unsaturated hydrocarbons by MoO3 using low H2 pressures, Energy Environ. Sci. 6 (2013) 1732. doi:10.1039/c3ee24360e.

[43] M. Shetty, K. Murugappan, T. Prasomsri, W.H. Green, Y. Román-Leshkov, Reactivity and stability investigation of supported molybdenum oxide catalysts for the hydrodeoxygenation (HDO) of m-cresol, J. Catal. 331 (2015) 86-97. doi:10.1016/j.jcat.2015.07.034. 
[44] T. Prasomsri, M. Shetty, K. Murugappan, Y. Román-Leshkov, Insights into the catalytic activity and surface modification of $\mathrm{MoO}_{3}$ during the hydrodeoxygenation of lignin-derived model compounds into aromatic hydrocarbons under low hydrogen pressures, Energy Environ. Sci. 7 (2014) 2660-2669. doi:10.1039/C4EE00890A.

[45] M.W. Nolte, J. Zhang, B.H. Shanks, Ex situ hydrodeoxygenation in biomass pyrolysis using molybdenum oxide and low pressure hydrogen, Green Chem. 18 (2015) 134-138. doi:10.1039/c5gc01614b.

[46] G. Zhou, P.A. Jensen, D.M. Le, N.O. Knudsen, A.D. Jensen, Atmospheric Hydrodeoxygenation of Biomass Fast Pyrolysis Vapor by MoO3, ACS Sustain. Chem. Eng. 4 (2016) 5432-5440. doi:10.1021/acssuschemeng.6b00757.

[47] K. Murugappan, C. Mukarakate, S. Budhi, M. Shetty, M.R. Nimlos, Y. Román-Leshkov, Supported molybdenum oxides as effective catalysts for the catalytic fast pyrolysis of lignocellulosic biomass, Green Chem. 18 (2016) 5548-5557. doi:10.1039/C6GC01189F.

[48] K. Wang, D.C. Dayton, J.E. Peters, O.D. Mante, Reactive catalytic fast pyrolysis of biomass to produce highquality bio-crude, Green Chem. 19 (2017) 3243-3251. doi:10.1039/c7gc01088e.

[49] D.P. Gamliel, G.M. Bollas, J.A. Valla, Two-stage catalytic fast hydropyrolysis of biomass for the production of drop-in biofuel, Fuel. 216 (2018) 160-170. doi:10.1016/j.fuel.2017.12.017.

[50] D.P. Gamliel, G.M. Bollas, J.A. Valla, Bifunctional Ni-ZSM-5 Catalysts for the Pyrolysis and Hydropyrolysis of Biomass, Energy Technol. 5 (2017) 172-182. doi:10.1002/ente.201600136.

[51] A. Galadima, O. Muraza, In situ fast pyrolysis of biomass with zeolite catalysts for bioaromatics/gasoline production: A review, Energy Convers. Manag. 105 (2015) 338-354. doi:10.1016/j.enconman.2015.07.078.

[52] S. Wan, Y. Wang, A review on ex situ catalytic fast pyrolysis of biomass, Front. Chem. Sci. Eng. 8 (2014) 280-294. doi:10.1007/s11705-014-1436-8.

[53] C. Liu, H. Wang, A.M. Karim, J. Sun, Y. Wang, Catalytic fast pyrolysis of lignocellulosic biomass, Chem. Soc. Rev. 43 (2014) 7594-7623. doi:10.1039/C3CS60414D.

[54] T.J. Mazanec, J.P. Whiting, F. Pesa, R. Song, Y.-T. Cheng, R. Song, Regeneration of catalytic fast pyrolysis, US 2014/0303414 A1, 2017.

[55] J. Shi, C. Sorensen, T. Mazanec, R. Song, S. Goud, S. Han, Y.-T. Cheng, V.L. Frank, J.W.F. Igoe, M. Schneidkraut, Improved catalytic fast pyrolysis process with impurity removal, WO2017003790A1, 2015.

[56] V. Paasikallio, C. Lindfors, E. Kuoppala, Y. Solantausta, A. Oasmaa, J. Lehto, J. Lehtonen, Product quality and catalyst deactivation in a four day catalytic fast pyrolysis production run, Green Chem. 16 (2014) 35493559. doi:10.1039/c4gc00571f.

[57] K.G. Kalogiannis, S.D. Stefanidis, A.A. Lappas, Catalyst deactivation, ash accumulation and bio-oil deoxygenation during ex situ catalytic fast pyrolysis of biomass in a cascade thermal-catalytic reactor system, Fuel Process. Technol. 186 (2019) 99-109. doi:10.1016/j.fuproc.2018.12.008.

[58] A. Dutta, J.A. Schaidle, D. Humbird, F.G. Baddour, A. Sahir, Conceptual Process Design and TechnoEconomic Assessment of Ex Situ Catalytic Fast Pyrolysis of Biomass: A Fixed Bed Reactor Implementation Scenario for Future Feasibility, Top. Catal. 59 (2016) 2-18. doi:10.1007/s11244-015-0500-z.

[59] J.T. Miller, M. Schreier, A.J. Kropf, J.R. Regalbuto, A fundamental study of platinum tetraammine impregnation of silica: 2. The effect of method of preparation, loading, and calcination temperature on (reduced) particle size, J. Catal. 225 (2004) 203-212. doi:10.1016/j.jcat.2004.04.007.

[60] M. Schreier, J.R. Regalbuto, A fundamental study of Pt tetraammine impregnation of silica: 1 . The electrostatic nature of platinum adsorption, J. Catal. 225 (2004) 190-202. doi:10.1016/j.jcat.2004.03.034.

[61] A. Eschenbacher, F. Goodarzi, A. Saraeian, S. Kegnæs, B.H. Shanks, A.D. Jensen, Performance of Mesoporous HZSM-5 and Silicalite-1 Coated Mesoporous HZSM-5 Catalysts for Deoxygenation of Straw Fast Pyrolysis Vapors, J. Anal. Appl. Pyrolysis. (2019) 104712. doi:10.1016/J.JAAP.2019.104712.

[62] A. Eschenbacher, P.A. Jensen, U.B. Henriksen, J. Ahrenfeldt, S. Ndoni, C. Li, J.Ø. Duus, U.V. Mentzel, A.D. Jensen, Catalytic deoxygenation of vapors obtained from ablative fast pyrolysis of wheat straw using mesoporous HZSM-5, Fuel Process. Technol. 194 (2019) 106119. doi:10.1016/J.FUPROC.2019.106119.

[63] S.A. Channiwala, P.P. Parikh, A unified correlation for estimating HHV of solid, liquid and gaseous fuels, Fuel. 81 (2002) 1051-1063. doi:10.1016/S0016-2361(01)00131-4.

[64] K. Schofield, The enigmatic mechanism of the flame ionization detector: Its overlooked implications for fossil fuel combustion modeling, Prog. Energy Combust. Sci. 34 (2008) 330-350. doi:10.1016/j.pecs.2007.08.001.

[65] M. Von Holle, J.R. Carpenter, D.C. Dayton, Reactive catalytic fast pyrolysis process and system, US 2019/0211268 Al, 2019. doi:10.1111/2047-8852.12112.

[66] D.C. Dayton, T. Member, A. Daniels, M. Company, Catalytic Deoxygenation of Biomass Pyrolysis Vapors to Improve Bio-oil Stability, n.d. 
[67] H. Ben, A.J. Ragauskas, Heteronuclear single-quantum correlation-nuclear magnetic resonance (HSQCNMR) fingerprint analysis of pyrolysis oils, Energy and Fuels. 25 (2011) 5791-5801. doi:10.1021/ef201376w.

[68] R.M. Happs, K. Iisa, J.R.F. Iii, Quantitative 13C NMR characterization of fast pyrolysis oils, RSC Adv. 6 (2016) 102665-102670. doi:10.1039/C6RA24044E.

[69] M.B. Griffin, K. Iisa, H. Wang, A. Dutta, K.A. Orton, R.J. French, D.M. Santosa, N. Wilson, E. Christensen, C. Nash, K.M. Van Allsburg, F.G. Baddour, D.A. Ruddy, E.C.D. Tan, H. Cai, C. Mukarakate, J.A. Schaidle, Driving towards cost-competitive biofuels through catalytic fast pyrolysis by rethinking catalyst selection and reactor configuration, Energy Environ. Sci. 11 (2018) 2904-2918. doi:10.1039/c8ee01872c.

[70] T.T. Pham, L.L. Lobban, D.E. Resasco, R.G. Mallinson, Hydrogenation and Hydrodeoxygenation of 2methyl-2-pentenal on supported metal catalysts, J. Catal. 266 (2009) 9-14. doi:10.1016/j.jcat.2009.05.009.

[71] J.G. Speight, Corrosion by High Acid Crude Oil, in: High Acid Crudes, Elsevier, 2014: pp. 57-75. doi:10.1016/B978-0-12-800630-6.00003-4.

[72] N.Y. Chen, D.E. Walsh, L.R. Koenig, Fluidized Bed Upgrading of Wood Pyrolysis Liquids and Related Compounds., ACS Div. Fuel Chem. Prepr. 32 (1987) 264-275. doi:10.1021/bk-1988-0376.ch024.

[73] S.D. Gray, K.J. Weller, M.A. Bruck, P.M. Briggs, D.E. Wigley, Carbon-Nitrogen Bond Cleavage in an $\eta 2(N$, C)-Pyridine Complex Induced by Intramolecular Metal-to-Ligand Alkyl Migration: Models for Hydrodenitrogenation Catalysis, J. Am. Chem. Soc. 117 (1995) 10678-10693. doi:10.1021/ja00148a010.

[74] T.N. Pham, T. Sooknoi, S.P. Crossley, D.E. Resasco, Ketonization of Carboxylic Acids: Mechanisms, Catalysts, and Implications for Biomass Conversion, ACS Catal. 3 (2013) 2456-2473. doi:10.1021/cs400501h.

[75] T.M.H. Dabros, M.Z. Stummann, M. Høj, P.A. Jensen, J.D. Grunwaldt, J. Gabrielsen, P.M. Mortensen, A.D. Jensen, Transportation fuels from biomass fast pyrolysis, catalytic hydrodeoxygenation, and catalytic fast hydropyrolysis, Prog. Energy Combust. Sci. 68 (2018) 268-309. doi:10.1016/j.pecs.2018.05.002.

[76] K.V. Raun, L.F. Lundegaard, J. Chevallier, P. Beato, C.C. Appel, K. Nielsen, M. Thorhauge, A.D. Jensen, M. Høj, Deactivation behavior of an iron-molybdate catalyst during selective oxidation of methanol to formaldehyde, Catal. Sci. Technol. 8 (2018) 4626-4637. doi:10.1039/c8cy01109e.

[77] K.I. Ivanov, D.Y. Dimitrov, Deactivation of an industrial iron-molybdate catalyst for methanol oxidation, in: Catal. Today, 2010: pp. 250-255. doi:10.1016/j.cattod.2010.03.051.

[78] K.V. Raun, M. Thorhauge, M. Høj, A.D. Jensen, Modeling of molybdenum transport and pressure drop increase in fixed bed reactors used for selective oxidation of methanol to formaldehyde using iron molybdate catalysts, Chem. Eng. Sci. 202 (2019) 347-356. doi:10.1016/j.ces.2019.03.020.

[79] J. Thrane, L.F. Lundegaard, P. Beato, U.V. Mentzel, M. Thorhauge, A.D. Jensen, M. Høj, Alkali Earth Metal Molybdates as Catalysts for the Selective Oxidation of Methanol to Formaldehyde-Selectivity, Activity, and Stability, Catalysts. 10 (2020) 82. doi:10.3390/catal10010082.

[80] A.P.V. Soares, M.F. Portela, A. Kiennemann, L. Hilaire, Mechanism of deactivation of iron-molybdate catalysts prepared by coprecipitation and sol - gel techniques in methanol to formaldehyde oxidation, Chem. Eng. Sci. 58 (2003) 1315-1322. doi:10.1016/S0009-2509(02)00573-0.

[81] K. Routray, W. Zhou, C.J. Kiely, W. Grünert, I.E. Wachs, Origin of the synergistic interaction between MoO3 and iron molybdate for the selective oxidation of methanol to formaldehyde, J. Catal. 275 (2010) 84-98. doi:10.1016/j.jcat.2010.07.023.

[82] CatCost, (n.d.). https://catcost.chemcatbio.org/ (accessed November 13, 2019).

[83] P.M. Mortensen, J.D. Grunwaldt, P.A. Jensen, A.D. Jensen, Influence on nickel particle size on the hydrodeoxygenation of phenol over Ni/SiO2, Catal. Today. 259 (2016) 277-284. doi:10.1016/j.cattod.2015.08.022.

[84] C. Newman, X. Zhou, B. Goundie, I.T. Ghampson, R.A. Pollock, Z. Ross, M.C. Wheeler, R.W. Meulenberg, R.N. Austin, B.G. Frederick, Effects of support identity and metal dispersion in supported ruthenium hydrodeoxygenation catalysts, Appl. Catal. A Gen. 477 (2014) 64-74. doi:10.1016/j.apcata.2014.02.030. 